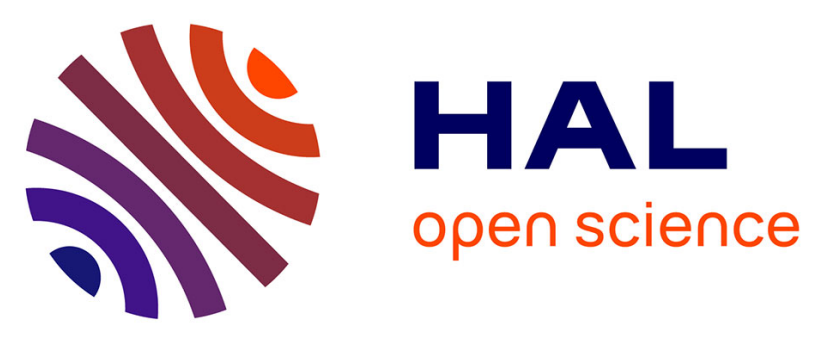

\title{
Production of exopolymers (EPS) by cyanobacteria: impact on the carbon-to-nutrient ratio of the particulate organic matter
}

Alexandrine Pannard, Julie Pédrono, Myriam Bormans, Enora Briand, Pascal Claquin, Yvan Lagadeuc

\section{To cite this version:}

Alexandrine Pannard, Julie Pédrono, Myriam Bormans, Enora Briand, Pascal Claquin, et al.. Production of exopolymers (EPS) by cyanobacteria: impact on the carbon-to-nutrient ratio of the particulate organic matter. Aquatic Ecology, 2016, 50 (1), pp.29-44. 10.1007/s10452-015-9550-3 . hal-01219377

\section{HAL Id: hal-01219377 \\ https://hal-univ-rennes1.archives-ouvertes.fr/hal-01219377}

Submitted on 22 Oct 2015

HAL is a multi-disciplinary open access archive for the deposit and dissemination of scientific research documents, whether they are published or not. The documents may come from teaching and research institutions in France or abroad, or from public or private research centers.
L'archive ouverte pluridisciplinaire HAL, est destinée au dépôt et à la diffusion de documents scientifiques de niveau recherche, publiés ou non, émanant des établissements d'enseignement et de recherche français ou étrangers, des laboratoires publics ou privés. 
3 Alexandrine Pannard*, Julie Pédrono, Myriam Bormans, Enora Briand, Pascal Claquin ${ }^{12}$, and Yvan 4 Lagadeuc

5 CNRS-UMR 6553 Ecobio, OSUR, University of Rennes 1, Campus de Beaulieu, bâtiment 14b, Av. 6 General Leclerc, Rennes, F-35 042, France

7 1- Université de Caen Basse-Normandie, BOREA, F-14032 Caen, France

8 2- BOREA CNRS 7208, IRD-207, MNHN, UPMC, UCBN, F-14032 Caen, France

9 *Corresponding author: alexandrine.pannard@univ-rennes1.fr

11 Abstract Freshwater cyanobacteria can produce large amount of mucilage, particularly during large blooms. The production of these carbon-rich exopolymers (EPS) should influence the carbon-tonutrient ratios of the organic matter $(\mathrm{OM})$, which are regularly used as a proxy for the herbivorous food quality. However, little is known about the consequences of EPS production on the carbon-tonutrient ratio of the OM. Two EPS forms can be distinguished: the free fraction composed of Soluble Extracellular Polymeric Substances (S-EPS) and the particulate fraction corresponding to the Transparent Exopolymer Particles (TEP). The aim of the study was to determine whether the TEP and S-EPS productions by cyanobacteria influence the carbon-to-nutrient ratios of the particulate OM (POM). Five cyanobacteria species were grown in batch culture and characterized in terms of photosynthetic activity, EPS production, and C, N, P contents. The variability in EPS production was compared with the variability in stoichiometry of the POM. Most of cyanobacteria live in association with heterotrophic bacteria (HB) within the mucilage. The effect of the presence/absence of HB on EPS production and the carbon-to-nutrient ratios of the POM was also characterized for the cyanobacteria Microcystis aeruginosa. We showed that TEP production increased the carbon-tonutrient ratios of the POM in the absence of $\mathrm{HB}$, while the stoichiometry did not significantly change when HB were present. The C:N ratio of the POM decreased with production of S- EPS by the five species. Lastly, the three colonial species (Chroococcales) tend to produce more TEP than the two filamentous species (Oscillatoriales), with the two picocyanobacteria being the most productive of both TEP and S-EPS. 
31 Keywords Transparent exopolymer particles; mucilage; stoichiometry; Microcystis aeruginosa

Introduction

Phytoplankton primary production represents one of the basic processes of pelagic ecosystem functioning, with the synthesis of a major source of organic carbon for heterotrophic communities (Cole, Likens \& Strayer 1982; Baines \& Pace 1991). The carbon-to-nutrient ratio of phytoplankton varies greatly compared with other aquatic heterotrophic organisms, depending on carbon fixation and nutrient uptake (Van de Waal et al. 2010). The nutritional value of the organic matter (OM) is partly controlled by the carbon-to-nutrient ratios (Sterner \& Elser 2002; Urabe, Togari \& Elser 2003; Van de Waal et al. 2010), with food quality for heterotrophic communities decreasing as stoichiometric ratios increase. Exopolymers (EPS) released by phytoplankton are carbohydrate-rich, and can thus potentially increase the carbon-to-nutrient ratios of the OM. In marine phytoplankton, it was shown that EPS composition can deviate in C:N far from the Redfield ratio, up to 26 (Engel \& Passow 2001). EPS production by phytoplankton is highly variable, from 1 to $99.9 \%$ of the net photosynthetically fixed organic carbon, depending on species and environmental conditions (Bertilsson \& Jones 2003). The presence of species producing large amount of EPS should control the elemental ratios (C:N, $\mathrm{C}: \mathrm{P})$ of the $\mathrm{OM}$ in pelagic ecosystems, with potential repercussions on the trophic network. A better characterization of the link between species, EPS production and stoichiometry of the POM is thus needed. commonly divided in two forms, one dissolved and one attached. They are rarely simultaneously characterized, so that little is known about this double production and its variability between and among species. A large portion of exudates corresponds to a dissolved fraction, which is called Soluble Extracellular Polymeric Substances (S-EPS) (Underwood, Paterson \& Parkes 1995; Staats et al. 1999; Underwood et al. 2004). Some phytoplankton species, particularly cyanobacteria, produce 
These cell-bounded EPS belong to the widely studied 'Transparent Exopolymer Particles' (TEP) in aquatic ecosystems (Passow \& Alldredge 1995). Depending on the form of EPS (dissolved or particulate), the influence of their production on the stoichiometry of the particulate organic matter should differ (POM). Production of TEP should increase the C:N and C:P of the POM, while S-EPS should decrease the stoichiometric ratios, owing to a carbon loss. Studies generally focused on one of the two forms of EPS, and the associated C:N and C:P ratios of the POM are rarely quantified.

In freshwater ecosystems, cyanobacteria are known to accumulate in dense blooms, with an increasing frequency and intensity due to global changes (Johnk et al. 2008). These blooms lead to high concentrations of TEP at the water surface (Grossart, Simon \& Logan 1997) and one can wonder if such 'TEP events' may induce a change in the carbon-to-nutrient ratios of the particulate OM. These blooms are generally dominated by a few species (Huisman, Matthijs \& Visser 2005). This raises the question of the species' role in determining the POM stoichiometry. Colonial species, such as Chroococcales, should produce more TEP compared with other pelagic species, such as singlefilament species. One can also wonder whether a lower TEP production is counterbalanced by a higher S-EPS production. TEP and S-EPS productions should differ between species depending on their morphological traits, and consequently their impact on the POM stoichiometry. factor for both TEP (Passow 2002; Reynolds 2007) and S-EPS (Baines \& Pace 1991; Myklestad 1995). When nitrogen (or phosphorus) become limiting for growth, phytoplankton still accumulate some carbon during photosynthesis, while storage and metabolic uses (proteins production, growth) are limited (Banse 1974; De Philippis \& Vincenzini 1998; Engel et al. 2004). The carbon in excess can be either excreted as polysaccharides, through the EPS (overflow) or stored in the cell through the formation of reserve compounds (De Philippis et al., 1996). However, less is known about the influence of heterotrophic bacteria (HB) on EPS production. Indeed, freshwater cyanobacteria are associated with highly diversified and metabolically active HB embedded in their mucilage (Worm \& Søndergaard 1998; Casamatta 2000; Berg et al. 2009). TEP constitute suitable habitat for the microorganisms. HB can modulate the magnitude of the effect of nutrient on EPS production, 
through mineralization of organic nutrients. HB can also influence directly TEP and S-EPS

concentrations through consumption and/or production of dissolved OM (Azam et al. 1994; Gärdes et al. 2012). Lastly, nutrients may modulate the magnitude of the effect of HB on EPS production: it has been demonstrated that nutrient availability influence the type of biological interaction between the green microalga Scenedesmus obliquus and HB (Danger et al. 2007).

The aim of the study was firstly to characterize the influence of HB and nutrient load on EPS production, and secondly to characterize the impact of EPS production by cyanobacteria (and their associated $\mathrm{HB}$ ) on the $\mathrm{C}: \mathrm{N}$ and $\mathrm{C}: \mathrm{P}$ ratio of the POM. In a first experiment, we characterize the effect of the presence of HB and nutrient load, on the EPS production by Microcystis aeruginosa and the associated C-to-nutrient ratios of the POM. We also test the hypothesis that the variability of the C-tonutrient ratio of the POM may be explained by the species variability in EPS production. In a second experiment, we characterize the C,N,P content and the TEP and S-EPS productions by cyanobacteria, with three colonial (Microcystis aeruginosa and the picocyanobacteria Aphanothece clathrata and A. minutissima) and two single-filament species (Limnothrix sp. and Planktothrix agardhii).

\section{Methods}

Cyanobacteria cultures:

Aphanothece clathrata (TCC 4a) and A. minutissima (TCC 323) were provided by the INRA - UMR Carrtel (Thonon Culture Collection), while Oscillatoria sp (LRP 29) and Planktothrix agaardhii are grown in routine in our laboratory. These four strains were all xenic. The axenic strain of Microcystis aeruginosa (PCC 7806) was provided by the Pasteur Culture collection of Cyanobacteria (http://cyanobacteria.web.pasteur.fr/). The axenic strain was initially checked for bacterial contamination by agar plating, following Briand et al. (2012). M. aeruginosa was grown in modified BG11 medium (Rippka 1988), while the four other strains were grown in BG11 medium (Andersen 2005). 
110 To test for the effect of the presence of HB on the EPS production and the C-to-nutrient ratios of the

111 POM, one of the five species, M. aeruginosa, was grown in both xenic (B) and axenic (Ax)

112 conditions, at two nitrates loads $(+\mathrm{N}$ and $-\mathrm{N})$. Initial nitrogen concentration was $1.76 \mathrm{mmol} \mathrm{N} \mathrm{L}^{-1}$ in

113 the classical N-replete medium $(+\mathrm{N})$ and was $0.178 \mathrm{mmol} \mathrm{N} \mathrm{L}^{-1}$ in the $\mathrm{N}$-depleted medium (-N). The

114 xenic culture of M. aeruginosa was obtained from the axenic one, after adding HB isolated from a

115 French pond (N 48 7'35.465',; W $\left.1^{\circ} 38^{\prime} 14.453^{\prime \prime}\right)$, where M. aeruginosa is regularly blooming. $2 \mathrm{~mL}$

116 of water from the pond was filtered on sterile $1 \mu \mathrm{m}$ Poretics polycarbonate membrane filters, and the

117 filtrate was added to $40 \mathrm{~mL}$ of $M$. aeruginosa axenic culture. This xenic culture (B) was grown in

118 batch for two months prior to the experiment, with two inputs of fresh medium (approximately each

119 three weeks). At the beginning of the experiment, the culture reached a total volume of $1.2 \mathrm{~L}$, so that

120 the initial input of pond water represents less than $0.2 \%$ of the total volume. Before and after the

121 experiment, we checked the presence of bacteria in the B culture, and for possible bacterial

122 contamination in the Ax culture, with epifluorescent microscopic observations of 1 to $5 \mathrm{~mL}$ sub-

123 samples on $0.2 \mu \mathrm{m}$ Nuclepore membranes after staining with DAPI (4'6-diamidino-2-phenylindole).

124 Even if we cannot totally exclude a possible contamination by small-sized cyanobacteria, neither

125 picocyanobacteria nor other small unidentified cells have been detected by regular microscopic

126 observations.

127 Experiment 1 (xenic versus axenic conditions):

128 M. aeruginosa was tested in the presence (B) and in the absence (Ax) of heterotrophic bacteria, at two 129 levels of nitrate availability $(+\mathrm{N}$ and $-\mathrm{N})$. Each treatment $(\mathrm{Ax}-\mathrm{N}, \mathrm{Ax}+\mathrm{N}, \mathrm{B}-\mathrm{N}, \mathrm{B}+\mathrm{N})$ was run in 130 triplicate in batch culture in climatic chambers at $25 \pm 1{ }^{\circ} \mathrm{C}, 14: 10$ light:dark cycle with $30 \mu \mathrm{mol}$ 131 photons $\mathrm{m}^{-2} \mathrm{~s}^{-1}$ irradiance, in $500 \mathrm{~mL}$ Erlenmeyers flasks. All the cultures were manually mixed daily.

132 Initial cell density of cyanobacteria was 200000 cells $\mathrm{mL}^{-1}$. Cultures were sampled every two days

133 until the early stationary phase, and characterized in terms of photosynthetic activity and cell density.

134 S-EPS, TEP and the C:N:P molar ratios of the OM were measured initially, during the exponential 135 growth and as soon as cultures reached the early stationary phase. 
137 The five species were grown in triplicate in batch culture in climatic chambers at $25 \pm 1{ }^{\circ} \mathrm{C}, 14: 10$

138 light:dark cycle with $30 \mu \mathrm{mol}$ photons $\mathrm{m}^{-2} \mathrm{~s}^{-1}$ irradiance, in 500mL Erlenmeyers flasks. All the 139 cultures were manually mixed daily. Initial cell density of cyanobacteria was 200000 cells $\mathrm{mL}^{-1}$.

140 Cultures were sampled every two days until the early stationary phase, and characterized in terms of 141 photosynthetic activity and cell density, as detailed below. S-EPS, TEP and the C:N:P molar ratios of 142 the OM were measured during the exponential growth and the early stationary phases. To limit 143 cyanobacteria cells lysis and release of EPS, the sampling at the early stationary phase was preferred 144 over the advanced stationary phase. The cultures were assumed to be in early stationary phase when cell density remained stable during two successive sampling dates (four consecutive days) and when a

146 decrease in the dark-adapted photochemical quantum efficiency Fv/Fm was observed.

147 Cell density and physiological measurements:

148 Cell density was inferred by the optical density (OD) absorbance following the literature (Svane \& 149 Eriksen, 2015 ; Post et al., 1985; Yepremian et al., 2007; Briand et al., 2008; Rorhlack et al., 2013). 150 The $680 \mathrm{~nm}$ wavelength (chlorophyll $a$ ) was preferred over $750 \mathrm{~nm}$ (turbidity), which would include 151 both bacteria and cyanobacterial cells (Danger et al. 2007). However, OD measured at $750 \mathrm{~nm}$ and $152680 \mathrm{~nm}$ were highly correlated both in the presence and absence of $\mathrm{HB}\left(\mathrm{R}^{2}>0.997, \mathrm{~N}=105, \mathrm{p}<\right.$ 1530.001 ; Fig. S1). The OD at $680 \mathrm{~nm}$ was converted into cell density (cells $\mathrm{mL}^{-1}$ ) based on the highly 154 significant correlations between the two parameters $\left(\mathrm{R}^{2}>0.99, \mathrm{~N}=26, \mathrm{p}<0.001\right.$; data not shown). 155 We considered as negligible the intraspecific variability in cell size. The absorbance was measured every two days using a spectrophotometer Uvikon XS (Secomam, France).

157

158

159

160

161 The maximum growth rate was calculated from the formula: $=\quad 2-(1) 2-1$ where $\quad 1$ and 2 correspond to the cell density $\left(\right.$ cells $\left.\mathrm{mL}^{-1}\right)$ at time $\mathrm{t} 1$ and $\mathrm{t} 2\left(\mathrm{day}^{-1}\right)$ respectively. Some filamentous species tend to form aggregates with time, increasing the daily variability in biomass measurement. The slope of the time series of the Neperian logarithm of the cell density (during the exponential growth) was thus preferred over instantaneous growth rate. 
164 To characterize the photosynthetic activity and the physiological state of the cyanobacteria, the

165 electron transport rate (ETR) and the photosynthetic yield were measured every two days with a pulse-

166 amplitude-modulated fluorescence monitoring system (PhytoPAM, Walz, Germany), following

167 Schreiber (1998) and Zhang et al. (2011). The phytoPAM is equivalent to 4 separate PAM-

168 Fluorometers using light-emitting-diodes (LED) with $10 \mu$ s light pulses at 4 different excitation

169 wavelengths $(470,520,645$ and $665 \mathrm{~nm}$ ), with the $645 \mathrm{~nm}$ specific to cyanobacteria (due to

170 phycocyanin and allophycocyanin absorption). The phytoPAM was used with only one channel,

171 corresponding to the cyanobacteria. The reference excitation spectrum measured at the factory was

172 used, as it was not significantly different from reference excitation spectra performed on our

173 cyanobacterial cultures. After dark-adaptation for $15 \mathrm{~min}$, fluorescence was measured at low

174 measuring light $\left(0.15 \mu \mathrm{mol}\right.$ photons $\left.\mathrm{m}^{-2} \mathrm{~s}^{-1}\right)$ and during saturating light pulses $\left(3000 \mu \mathrm{mol}\right.$ photons $\mathrm{m}^{-2}$

$175 \mathrm{~s}^{-1}$ for $0.2 \mathrm{~s}$ ). Fluorescence was measured at 10 different intensities of actinic light from 1 to 1216

$176 \mu \mathrm{mol}$ photons $\mathrm{m}^{-2} \mathrm{~s}^{-1}$, with a 20 -s time interval. The initial chlorophyll $a$ fluorescence was also

177 measured on each sample.

178 During the exponential growth and the stationary phase, the chlorophyll-specific absorption cross-

179 section $a^{*}\left(\mathrm{~m}^{2} \mathrm{mg} \operatorname{chl} a^{-1}\right)$ was measured from in vivo absorption spectra of the cyanobacteria between

180400 and $750 \mathrm{~nm}$ and from the chlorophyll $a$ concentration, following Shibata et al. (Shibata, Benson \&

181 Calvin 1954). The ETR ( $\mu \mathrm{mol}$ electron $\mathrm{mg} \operatorname{chl} a^{-1} \mathrm{~s}^{-1}$ ) was then calculated for each light intensity $I$

182 following Kromkamp and Forster (2003):

183

$$
\mathrm{ETR}=0.5 Y I a^{*}
$$

184 with 0.5 corresponding to the $50 \%$ of photons intercepted by the PSII of the chlorophyll- $a$ (Gilbert,

185 Wilhelm \& Richter 2000). $Y$ represents the quantum efficiency of the PSII and $I$ the light intensity.

186 The non-linear least squares regression model of Eilers and Peeters (1988) was used to fit the ETR

187 irradiance curves and to estimate the physiological parameters, such as the light saturated maximum

188 electron transport rate ETRmax. 
190 To separate cells from the supernatant, centrifugation at $3200 \mathrm{xg}$ for $30 \mathrm{~min}$ at $12^{\circ} \mathrm{C}$ was performed

191 following Claquin et al. (2008). TEP and S-EPS were then analyzed separately.

192 The method of Passow and Alldredge (1995) modified by Claquin et al. (2008) was used to quantify

193 the TEP fraction in $10 \mathrm{~mL}$ of culture. Briefly, two $\mathrm{mL}$ of $0.02 \%$ alcian blue in $0.06 \%$ acetic acid were

194 added to the pellets, and samples were centrifuged at $3200 \mathrm{x} \mathrm{g}$ at $4{ }^{\circ} \mathrm{C}$ for $20 \mathrm{~min}$. Pellets were rinsed

195 with $2 \mathrm{~mL}$ of distilled water and centrifuged again until the supernatant remained clear, in order to

196 evacuate the excess of alcian blue. $4 \mathrm{~mL}$ of $80 \%$ sulfuric acid were then added to the pellets.

197 Absorbance was measured at $787 \mathrm{~nm}$ after $2 \mathrm{~h}$ and converted in equivalent xanthan (Passow \&

198 Alldredge 1995). A calibration curve was performed using xanthan gum following the same protocol.

199 Xanthan was then converted in equivalent carbon using the factor of 0.75 observed by Engel and

200 Passow (2001).

201 S-EPS were quantified using the method of Dubois et al. (1956). Briefly, $0.5 \mathrm{~mL}$ of supernatant was

202 placed in a glass tube with $1 \mathrm{~mL}$ of $5 \%$ phenol solution and $5 \mathrm{~mL}$ of $80 \%$ sulfuric acid. After $30 \mathrm{~min}$, 203 absorption was measured at $485 \mathrm{~nm}$ and converted in equivalent glucose, using a standard calibration 204 of glucose. Glucose was also converted in carbon, using the factor of 0.4 as for hexoses.

$205 C, N, P$ measurements:

206 To separate cells from the medium, centrifugation at $3200 \mathrm{xg}$ for $30 \mathrm{~min}$ at $12{ }^{\circ} \mathrm{C}$ was performed as 207 for EPS fractionation. Medium and particulate matter were then analyzed separately. To remove the 208 excess of surface-adsorbed $\mathrm{C}, \mathrm{N}$ and $\mathrm{P}$, pellets were briefly rinsed with distilled water and centrifuged 209 a second time at $3200 \mathrm{x}$ g for $20 \mathrm{~min}$.

210 Pellets were then resuspended in five $\mathrm{mL}$ of deionized water and analyzed for $\mathrm{C}, \mathrm{N}, \mathrm{P}$ content. Total

211 particulate organic carbon was measured with an high-temperature persulfate oxidation technology

212 using an OI Analytical carbon analyzer (model 1010 with a 1051 auto-sampler; Bioritech, France)

213 following the European standard ISO 8245 (1999). Total particulate nitrogen and total particulate

214 phosphorus were measured, after an acidic digestion with potassium persulfate at $120^{\circ} \mathrm{C}$, using a 215 continuous flow Auto-Analyser (Brann and Luebbe, Axflow, France), based on colorimetric methods 
217 were than calculated, by dividing $\mathrm{C}$ content by $\mathrm{N}$ and $\mathrm{P}$ content respectively.

218 The supernatant was divided in two samples, with one analyzed for nitrates and phosphates and the

219 second one for total dissolved nitrogen and total dissolved phosphorus after mineralization through a 220 potassium persulfate digestion at $120^{\circ} \mathrm{C} . \mathrm{N}$ and $\mathrm{P}$ concentrations were then measured using a 221 continuous flow Auto-Analyser (Brann and Luebbe, Axflow, France), based on colorimetric methods 222 according to Aminot and Chaussepied (1983).

\section{Statistical analysis}

225 All statistical analyses (boxplot, correlation, ordination, linear model) were carried out using R studio software (R Development Core Team 2011). Wilcoxon rank-sum test followed by a post-hoc Tukey test were used to detect differences between species and treatments, with significance threshold set at 0.05 .

Linear models were used to examine the best set of predictor variables affecting the EPS production and the molar stoichiometric ratios of the POM produced by M. aeruginosa. One can expect nutrient 231 load to modulate the effect of the presence of HB on EPS production and vice versa. We thus test for statistical interactions between nutrient load and HB in the models. As models for $\mathrm{C}: \mathrm{N}$ and $\mathrm{C}: \mathrm{P}$ revealed the same set of explanatory parameters, only the C:N model will be presented here (see

234 supplementary data for the C:P model). Before analysis, data were checked to meet the assumptions of 235 normality and homoscedasticity. A stepwise selection of the variables, which combines backward 236 elimination and forward selection, was used to build the model, using the function "stepAIC" 237 (package MASS version 7.3-31 for R). The 'best' final model showed the lowest Akaike Information 238 Criterion (Sugiura 1978). The significance of the model was tested using an ANOVA, while a 239 Shapiro-Wilk normality test was performed on the residuals of the model.

240 To highlight controlling factors of the EPS production and C:N ratio in the five species of 241 cyanobacteria, multivariate approach has been used on centered and scaled data. Explanatory variables 242 were first reduced using forward selection of constraints with the forward.sel function of the 'packfor ' 
243 library developed by S. Dray, as advised by Blanchet et al. (2008). Monte Carlo permutations tests

244 retained only explanatory variables with probability value lower than 0.05 . Redundancy analysis

245 (RDA) was then performed with significant explanatory variables using 'vegan' library (Oksanen

246 2013). This constrained multivariate analysis detects and quantifies the modifications in the biological

247 response (TEP, S-EPS and C:N and N:P ratios of the POM), which can be explained by biological

248 parameters of the species (surface : volume ratio and growth rate) and the availability of the resource

249 (nitrates and phosphates concentration in the medium), through a multiple regression. While the

250 canonical analysis requires a unimodal relationship between the environmental parameters and the

251 biological response (typically environmental gradient analysis), the RDA underlies a linear

252 relationship. The significance of the RDA was tested through a permutation test.

\section{Results}

Experiment 1: the influence of $H B$.

To highlight the influence of HB and nutrient load on the stoichiometry of the POM, EPS productions and stoichiometric ratios were first measured in M. aeruginosa in the presence and in the absence of bacteria, at two nitrates loads. Dissolved inorganic phosphorus (DIP) in the medium was always higher than $96.9 \mu \mathrm{mol} \mathrm{P} \mathrm{L} \mathrm{L}^{-1}$ throughout the experiment, indicating that phosphorus was never

260 limiting in our experiment. $\mathrm{N}^{-\mathrm{NO}_{3}}{ }^{-}$concentration in the medium remained higher than $570 \mu \mathrm{mol} \mathrm{N} \mathrm{L}{ }^{-1}$

261 in nutrient replete condition (+ N), while the concentration was lower than $3.5 \mu \mathrm{mol} \mathrm{N} \mathrm{L}{ }^{-1}$ during the 262 stationary phase in nutrient depleted conditions (-N) (data not shown). Neither the bacterial presence 263 nor the two levels of nitrates availability induced a significant effect on the photosynthetic activity of 264 M. aeruginosa, measured through the ETRmax (Fig. 1). Only growth phase changed significantly the 265 ETRmax, in accordance with the decrease in photosynthetic activity when reaching the stationary 266 phase (Fig. 1). TEP and S-EPS productions were also influenced by growth phase (Fig. 2): TEP tend 267 to increase during the stationary phase (Fig. 2A), while S-EPS was at least three times higher during 268 the exponential growth phase than during the stationary phase (Fig. 2B). The productions of TEP and 
S-EPS showed a similar pattern, in response to nutrient availability and the presence of $\mathrm{HB}$, with a

270 predominating effect of bacteria during the exponential growth and a predominating effect of nutrient

271 during the stationary phase (Fig. 2). Low nitrate availability (-N ; nitrate concentrations $<15 \mu$ mol N

$272 \mathrm{~L}^{-1}$; data not shown) increased both TEP and S-EPS concentrations, during the stationary phase (Fig.

273 2). The presence of HB increased TEP during the exponential phase when associated with high nitrate

274 availability (Fig. 2A), leading to a significant interaction between HB and nitrates as shown by the

275 linear model (Table 2). The presence of HB (B versus Ax) increased significantly (two fold) the S-

276 EPS concentrations during the exponential phase (Fig. 2B).

TEP and S-EPS productions were then compared with modifications of the molar

278 stoichiometric ratios of the POM. The $\mathrm{C}: \mathrm{N}$ ratio of the POM was highly correlated with TEP in axenic 279 conditions (Fig. 3A). There was no significant correlation in the case of the C:P ratio (Fig. 3B). POM 280 associated with bacteria $(+B)$ showed more variable stoichiometric ratios, with lower values compared 281 with axenic condition (Fig. 3).

282 Linear models were used to examine the best set of predictor variables for the molar stoichiometric

283 ratios in M. aeruginosa. The initial model includes the amount of TEP and S-EPS per cell, the 284 concentration of nitrates and phosphates in the medium, the presence of HB (included as a qualitative 285 factor), and the ETRmax. Interactions between bacteria and TEP and between bacteria and nutrients 286 were also included in the initial model, bacterial activities being able to influence both TEP and 287 nutrients. Regression slopes significantly differed in the presence and in the absence of HB, indicating 288 that the magnitude of the effect of TEP and nitrates on the C:N ratio depends on the presence/absence 289 of bacteria. The best model for the C:N ratio (Table 3), determined by a stepwise selection of the 290 variables using the AIC criterion, selected the amount of TEP per cell, the nitrate concentration in the 291 medium, the presence/absence of HB, and two interactions, both with bacteria. In M. aeruginosa, TEP 292 increased C:N, while the presence of bacteria and the availability of nitrate decreased them (Table 3). 293 For both interactions (TEP x HB and nitrates $x$ HB), the presence of bacteria increased the effect's 294 magnitude of the factor (TEP or nitrates) on C:N ratio. In the presence of $\mathrm{HB}$, the C:N increased faster 295 with TEP and decreased faster with nitrate availability, compared with axenic conditions. 
Experiment 2:

Variability among species in EPS production and stoichiometry:

299 The five species of cyanobacteria were grown in the presence of $\mathrm{HB}$, with initially high nitrates load. 300 Stationary phases were observed after 15 to 24 days, depending on cultures (Fig. 4). The filamentous 301 cyanobacteria (Limnothrix and Planktothrix) were the first cultures reaching the stationary phase, but 302 the maximum cell density was two to three times lower than for the other species (Fig. 4). Their 303 growth rate remained low $\left(0.08 \pm 0.01\right.$ and $0.13 \pm 0.01$ day $^{-1}$ respectively), while the growth rates of 304 the three Chroococcales was higher than 0.25 day $^{-1}$. A. clathrata showed the highest growth rate, with $3050.49 \pm 0.01 \mathrm{day}^{-1}$, but this occurred only during the seven first days (Fig. 4). M. aeruginosa and A. 306 minutissima showed similar growth rates, with $0.28 \pm 0.03$ and $0.30 \pm 0.03$ day $^{-1}$ respectively. The 307 ETRmax measured during the exponential growth phase was also higher for the three Chroococcales, 308 compared with the Oscillatoriales, with the highest ETRmax observed for M. aeruginosa (Fig. 5). The 309 ETRmax decreased for all species when they reached the stationary phase (Fig. 5), as well as the dark310 adapted photochemical quantum efficiency $(\mathrm{Fv} / \mathrm{Fm})$, indicating the onset of the stationary phase (data 311 not shown).

312 While Chroococcales and Oscillatoriales differed in their growth rate during the exponential phase, 313 they also differed in their TEP production (Fig. 6A), contrary to the S-EPS production and POM's 314 stoichiometry (Fig. 6B, C and D). EPS productions by the five cyanobacteria species, and particularly 315 the picocyanobacteria, showed a high variability among replicates, larger than the variability among 316 species (Fig. 6A and B). However, species producing large amounts of S-EPS (Fig. 6A) tended to 317 produce large quantities of TEP (Fig. 6B). For the three Chroococcales, S-EPS production decreased 318 with growth phase (data not shown), as observed in the previous experiment (Fig. 2B).

319 The five species differ significantly in their molar C:N and C:P ratios, with a low variability among 320 replicates, except for the C:P of Planktothrix (Fig. 6C and D). Consequently, variability in the C:N 321 ratio was larger among species than among replicates (Fig. 6C and D). All species together, the C:N 
ratio was close to the reference value found in the literature (Passow 2002; Thornton 2002; Reynolds

323 2006), with on average $6.5 \pm 3.0$, a minimum of 1.9 and a maximum of 13.7 (Fig. 6C). The two

324 picocyanobacteria showed the same $\mathrm{C}: \mathrm{N}$ ratio, with values closed to 6 , while $M$. aeruginosa had the 325 highest $\mathrm{C}: \mathrm{N}$ ratio with $10.7 \pm 2.2$ (Fig. 6C). Limnothrix had the smallest $\mathrm{C}: \mathrm{N}$ ratio, with less than 4 , 326 while P. agardhii was closed to 8 (Fig. 6C). The C:P ratio (Fig. 6D) followed the same pattern than 327 the $\mathrm{C}: \mathrm{N}$ ratio (Fig. $6 \mathrm{C}$ ). While molar $\mathrm{C}: \mathrm{N}$ and $\mathrm{C}: \mathrm{P}$ ratios showed the same pattern among the species, 328 the TEP and the S-EPS production and stoichiometric ratios varied independently between species 329 (Fig. 6). The correlation between TEP production and C:N ratio observed in axenic condition at the 330 specific level (Fig. 3A) was not confirmed at the interspecific level.

Influence of EPS production on $C, N, P$ contents and stoichiometry of cyanobacteria:

333 The C, N, P contents of the POM were plotted for the five species (see symbols), for both growth 334 phases (white versus black symbols), and for the three replicates, as a function of the TEP content 335 (Fig. 7). Some species, like the two Aphanothece, showed a great variability in TEP content, 336 associated with their growth phase, while their $\mathrm{C}, \mathrm{N}$ and $\mathrm{P}$ contents changed only little (Fig. 7). All 337 species taken into account, the carbon content of the POM was correlated with the amount of TEP 338 (Fig. 7A), as well as the amount of nitrogen (Fig. 7B) and phosphorus (Fig. 7C). TEP is thus 339 associated with a simultaneous increase of the C,N,P contents of the POM (Fig. 7). On average, 340 increasing TEP content of 1 pg eq. C per cell led to an increase of $4 \mathrm{pg} \mathrm{C}, 0.4 \mathrm{pg} \mathrm{N}$ and $0.07 \mathrm{pg} \mathrm{P}$ of 341 the cell (Fig. 7). The POM increase associated with TEP production thus presented a C:N and a C:P 342 ratio of 11.7 and 140 respectively, which correspond to the highest ratios measured during the study 343 (Fig. 6C and D). Lastly, when comparing C:N ratio of the POM with the concentration of S-EPS in the 344 medium, a decrease of the C:N with larger concentration of S-EPS was observed (Fig. 8), indicating a 345 potential loss of the particulate carbon with S-EPS production. Similarly to the TEP content, some 346 species showed a great variability in EPS production, such as A. minutissima and Limnothrix, with 347 only few changes in the C:N ratio of the POM (Fig. 8). 
348 A redundancy analysis was performed to explain the $\mathrm{C}: \mathrm{N}$ and $\mathrm{N}: \mathrm{P}$ ratios and the EPS productions

349 with species parameters and nutrients availability. The N:P ratio was preferred over the C:P ratio in 350 the RDA analysis, because of the strong correlation between $\mathrm{C}: \mathrm{N}$ and $\mathrm{C}: \mathrm{P}\left(\mathrm{R}^{2}=0.77, \mathrm{p}<0.0001\right)$. The

351 RDA triplot showed that species and growth phases are well separated in the ordination space (Fig. 9).

352 The filamentous cyanobacteria are grouped together on the left part of the triplot, whatever their 353 growth rate, with the picocyanobacteria in stationary phase. The second axis separated M. aeruginosa 354 depending on its growth phase from the picocyanobacteria in exponential phase. The first axis (38\% 355 of the total variance) of the ordination was mainly described by TEP, and in a lower extent by S-EPS 356 and $\mathrm{C}: \mathrm{N}$. The explanatory variables of the first axis were the phosphates concentration and the cellular 357 surface on volume ratio (S:V ratio), which were opposite to nitrates concentration. Species in the right 358 part of the graph thus presented a higher C:N ratio and higher EPS productions, associated with high 359 phosphates availability and low nitrates one in the medium. These species also presented a higher 360 cellular S:V ratio. The second axis ( $25 \%$ of the total variance) was mainly described by S-EPS and 361 C:N, with species presenting a high C:N producing low S-EPS. The nitrates concentration and the 362 growth rate explained the second axis. Species with high C:N ratio showed a low growth rate in a 363 nitrate depleted medium.

\section{Discussion}

367 the end of phytoplankton blooms (Grossart et al. 1997; Passow 2002; Vieira et al. 2008). These POM are rapidly colonized by heterotrophic bacteria (Mari \& Kiørboe 1996), forming hotspots with 369 elevated microbial activity and nutrient cycling, particularly as cells become senescent. But, HB also 370 colonize healthy phytoplankton. For instance, numerous specific bacteria are embedded in the colonies

371 of Microcystis (Brunberg 1999; Casamatta 2000). It has been shown that many bloom-associated-

372 bacteria can enhance the cyanobacterial growth (Berg et al. 2009). Moreover, there is increasing 373 evidences of mutualistic relationships between phytoplankton and attached bacteria (Passow 2002; 
374 Croft et al. 2005). This may be a reason why axenic strains can be more difficult to maintain for long

375 periods in algal culture banks. In our study, the presence of heterotrophic bacteria did not affect

376 significantly the growth of $M$. aeruginosa, neither positively nor negatively. The maximum

377 photosynthetic activity, the mean growth rate and the final cell density of the cyanobacteria were

378 indeed similar in the presence and in the absence of HB. No significant cost neither benefice for the

379 cyanobacteria could be identified from this biotic interaction. However, the presence of HB was

380 associated with a higher EPS production, of both TEP and S-EPS, during the exponential growth

381 phase of M. aeruginosa. HB can have produced these additional TEP, even if previous studies showed

382 that HB associated with the mucilage of M. aeruginosa produced negligible TEP and S-EPS amounts

383 (Yallop, Paterson \& Wellsbury 2000; Shen et al. 2011). Recent studies on HB-phytoplankton

384 interactions also showed that HB can stimulate TEP release by marine diatoms (Bruckner et al. 2008;

385 Gärdes et al. 2012). Increasing TEP production by phytoplankton means higher C-rich organic matter

386 available for heterotrophic bacteria, which can in turn mineralize organic nitrogen and phosphorus.

387 The higher EPS production observed in our experiment occurred under nutrient replete conditions,

388 when mineralization of OM was not essential to support the growth of cyanobacteria. The stimulation

389 is thus not expected here. The additional TEP observed here were thus produced either by HB

390 themselves or by the cyanobacteria after a stimulation of release induced by the HB. The higher S-EPS

391 concentration observed in the medium can be explained by the hydrolytic activity of HB on TEP. The

392 relationship between HB and EPS is complex, as bacteria are involved in both production,

393 modification and degradation of EPS (Passow 2002). As we have no abundance estimates of HB,

394 neither any measure of their diversity and biological activity, we are limited to these hypotheses.

395 Coupling isotopic tracers with imaging mass spectrometry analysis (NanoSIMS) would be a powerful

396 approach to highlight $\mathrm{C}$ and $\mathrm{N}$ transfers from the cyanobacteria to the heterotrophic bacteria, as

397 performed with earthworms in their burrow-lining (Gicquel et al. 2012) or in N transfer within single

398 filament of cyanobacteria (Ploug et al. 2010). 
ratio of the POM was increased by TEP production, with a slope of +6.5 for each added picogram of

402 TEP (in equivalent C) to the cell. TEP, mainly composed of polysaccharides (De Philippis \&

403 Vincenzini 1998), are C-enriched compared with living biomass. TEP remaining attached to the POM,

404 their accumulation should increase the $\mathrm{C}: \mathrm{N}$ ratio of the POM. The C:N ratio of natural TEP from the 405 sea regularly exceeds 20 (Mari et al. 2001). However, we observed that the C:N ratio of the POM in 406 the presence of HB was not influenced by the TEP amount, so that the carbon-to-nutrient ratios of the 407 five species did not increase with TEP production. Hence, we conclude that TEP production increased 408 the C:N ratio of the POM, until colonization of the POM by HB. The presence of HB was indeed 409 associated with an increase of $\mathrm{N}$ and $\mathrm{P}$ contents of the POM, consequently modulating the effect of 410 TEP production on the stoichiometry of the POM. One can also hypothesize that cells of 411 cyanobacteria themselves influenced the $\mathrm{C}: \mathrm{N}: \mathrm{P}$ ratio of the POM through their storage capacity 412 (Kromkamp 1987; Klausmeier, Litchman \& Levin 2004). Indeed, cyanobacteria may accumulate P as 413 polyphosphate, as well as $\mathrm{N}$ as cyanophycin, both in granules in the cytoplasm (Kromkamp 1987;

414 Marañón et al. 2013). However, storage would also have occurred in the absence of HB. Heterotrophic 415 bacteria, through their activity and/or biomass, may have led to a $\mathrm{N}$ and $\mathrm{P}$ enrichment of the POM, 416 resulting to the simultaneous increase of the $\mathrm{C}, \mathrm{N}$ and $\mathrm{P}$ contents of the POM with TEP, as observed 417 here. The C:N of HB, which is also highly variable (Chrzanowski et al. 1996), tend to be slightly 418 lower than the Redfield ratio (C:N:P of 106:16:1) (Redfield, Ketchum \& Richards 1963), with about 5, 419 while the $\mathrm{C}: \mathrm{P}$ is twice to five times smaller, with values going from 50 to 19 depending on bacterial 420 growth rate and nutrient availability (Chrzanowski et al. 1996; Fagerbakke, Heldal \& Norland 1996).

$421 \mathrm{~N}$ is mainly associated with proteins and nucleic acids, while $\mathrm{P}$ is associated with nucleic acids (20\% 422 of the mass of the cell) and storage through polyphosphate granules (Fagerbakke et al. 1996). The C:N 423 and C:P ratios of the POM should thus decrease with bacterial colonization, compensating the increase 424 associated with TEP production. In natural aggregates, HB can represent up to $50 \%$ of the total protein 425 of the aggregates (Simon et al. 2002). 
zooplankton can become limited by nitrogen or phosphorus if the C-to-nutrient ratio of their food is

429 too high (Boersma \& Kreutzer, 2002). Their growth and reproduction is then affected, but not their life

430 span (Jensen \& Verschoor 2004). If the C-to-nutrient ratios are too high, or even too low (Boersma \&

431 Elser, 2006), heterotrophic grazers must eliminate the molecule in excess, as many organisms are

432 strongly homeostatic in their elemental composition. EPS production associated with the presence of

433 HB did not change here the carbon-to-nutrient ratios of the POM and probably the nutritional quality

434 of the food. This is in accordance with previous studies. For example, a cladocera Ceriodaphnia

435 cornuta fed with TEP released from the cyanobacteria Anabaena spiroides presented a higher growth

436 rate and a higher fitness compared with the cladocera fed on seston at natural concentration (Choueri

437 et al. 2007). TEP were obtained from filtrate of cultures in stationary phase, after evaporation, dialyze

438 and lyophilisation. However, the nutritional quality of the TEP is controversial in the literature, as

439 several studies reported a negative impact of TEP on zooplankton grazing, hypothesizing either an

440 allelochemical activity or an inhibitory effect of the EPS or protection against digestion (Decho \&

441 Lopez 1993; Liu \& Buskey 2000; Dutz, Breteler \& Kramer 2005). Specific allelochemicals might

442 have been produced in association with the EPS, as for instance for the toxic species Phaeocystis

443 (Dutz et al. 2005), in response to grazing pressure. While the nutritional quality may not have been

444 affected, its quantity was, as TEP and HB increased the C, N, P contents of the POM. HB attached to

445 aggregates become available as food for larger organisms (Passow \& Alldredge 1999). Ling and

446 Alldredge (2003) hypothesized that the consumption of TEP partly shunts organic carbon from the

447 microbial loop to higher trophic levels. A higher size structure of the herbivorous community may be

448 expected in the presence of TEP producing species.

449 Contrary to our expectation, no trade-off between the free fraction and the particulate form has

450 been observed. Species producing more S-EPS also tend to produce more TEP, compared with the

451 other species. Size controlling the S:V ratio and colony formation requesting TEP to embedded cells, a

452 higher TEP production was expecting for small-cell size and colonial species. The smallest species

453 (picocyanobacteria) thus showed the highest production of both forms of EPS, but also the greatest

454 variability. Marine studies, including a greater number of species, revealed no relationship between 
455 size and EPS production (López-Sandoval et al. 2013). The most probable hypothesis is that life form

456 is the predominant factor controlling EPS production. The three colonial species Chroococcales $(M$.

457 aeruginos $a$ and the picocyanobacteria) tend to produce more TEP than our two filamentous

458 cyanobacteria. The large production of TEP may correspond to the functional trait 'colonial

459 mucilaginous species': M. aeruginosa aggregates can contain millions of cells, while the

460 picocyanobacteria remained in small aggregates with generally less than 50 cells (Callieri \& Stockner

461 2002; Costas et al. 2008), but with a large proportion of mucilage relative to cell volume. Colony

462 forming species may be seen as 'suspended biofilm', with mucilage filling functions of cohesion,

463 protection, retention or exchange (Flemming \& Wingender, 2010). EPS production, and particularly

464 TEP, constitutes a functional trait, whose ecological roles are still discussed probably due to a

465 multiplicity of its functions (Reynolds, 2007).

466

467 Acknowledgements

468 This research was funded by a grant from CNRS-UMR 6553 Ecobio and research funds from the

469 University of Rennes (« Action incitative, Projets scientifiques émergents $2011 »$ ) and from the french

470 INSU-EC2CO program ('Microflux' 2012). We thank Nathalie Josselin-Le Bris and Marie-Paule

471 Briand for laboratory assistance. Bio-chemical analysis, microscopy and experimental chambers were

472 support by the common technical centers from the UMR Ecobio: the Analysis Biogeochemical center

473 (ABGC), the optical and digital imaging center (COIN) and the Ecology experimental center

474 (ECOLEX). We thank the two anonymous referees for helpful comments on an earlier version of the

475 manuscript. 
478 ISO 82451999 I.8. (1999) Water quality - Guidelines for the determination of total organic carbon

479 (TOC) and dissolved organic carbon (DOC).

480 Aminot A. \& Chaussepied M. (1983) Manuel des analyses en milieu marin. Brest.

481 Andersen R.A. (2005) Algal Culturing Techniques. Academic Press.

482 Azam F., Smith D.C., Steward G.F. \& Hagström A. (1994) Bacteria-organic matter coupling and its significance for oceanic carbon cycling. Microbial Ecology 28, 167-179.

484 Baines S.B. \& Pace M.L. (1991) The production of dissolved organic matter by phytoplankton and its importance to bacteria: patterns across marine and freshwater systems. Limnol. Oceanogr 36, 10781090.

487 Banse K. (1974) On the interpretation of data for the carbon-to-nitrogen ratio of phytoplankton.

488 Limnol. Oceanogr 19, 695-699.

489 Berg K.A., Lyra C., Sivonen K., Paulin L., Suomalainen S., Tuomi P., et al. (2009) High diversity of 490 cultivable heterotrophic bacteria in association with cyanobacterial water blooms. The ISME Journal $4913,314-325$.

492 Bertilsson S. \& Jones J.B. (2003) Supply of dissolved organic matter to aquatic ecosystems:

493 autochthonous sources. (Eds F. SEG \& S. RL), Academic Press.

494 Blanchet F.G., Legendre P. \& Borcard D. (2008) Forward selection of explanatory variables. Ecology

495 89, 2623-2632.

496 Boersma, M., \& Elser, J. J. (2006). Too much of a good thing: on stoichiometrically balanced diets 497 and maximal growth. Ecology, 87(5), 1325-1330.

498 Boersma, M., \& Kreutzer, C. (2002). Life at the edge: is food quality really of minor importance at 499 low quantities? Ecology, 83(9), 2552-2561.

500 Briand E, Yéprémian C, Humbert J F, Quiblier C (2008) Competition between microcystin- and non501 microcystin-producing Planktothrix agardhii (Cyanobacteria) strains under different environmental 502 conditions. Environmental Microbiology, 10(12): 3337-3348.

503 Briand E., Bormans M., Quiblier C., Salençon M.-J. \& Humbert J.-F. (2012) Evidence of the Cost of 504 the Production of Microcystins by Microcystis aeruginosa under Differing Light and Nitrate 505 Environmental Conditions. PLoS ONE 7, e29981.

506 Bruckner C.G., Bahulikar R., Rahalkar M., Schink B. \& Kroth P.G. (2008) Bacteria Associated with 507 Benthic Diatoms from Lake Constance: Phylogeny and Influences on Diatom Growth and Secretion of 508 Extracellular Polymeric Substances. Applied and Environmental Microbiology 74, 7740-7749.

509 Brunberg A.K. (1999) Contribution of bacteria in the mucilage of Microcystis spp.(Cyanobacteria) to 510 benthic and pelagic bacterial production in a hypereutrophic lake. FEMS Microbiology Ecology 29, $511 \quad 13-22$.

512 Callieri C. \& Stockner J.G. (2002) Freshwater autotrophic picoplankton: a review. Journal of 513 Limnology 61, 1-14.

514 Casamatta D.E.A. (2000) Sensitivity of Two Disjunct Bacterioplankton Communities to Exudates 515 from the Cyanobacterium Microcystis aeruginosa Kutzing. Microbial Ecology, 41, 64-73.

516 Choueri R.B., Melao M.D.G.G., Lombardi A.T. \& Vieira A.A.H. (2007) Effects of cyanobacterium 517 exopolysaccharides on life-history of Ceriodaphnia cornuta SARS. Journal of Plankton Research 29, 518 339-345.

519 Chrzanowski T.H., Kyle M., Elser J.J. \& Sterner R.W. (1996) Element ratios and growth dynamics of 520 bacteria in an oligotrophic Canadian shield lake. Aquatic Microbial Ecology 11, 119-125. 
Claquin P., Probert I., Lefebvre S. \& Véron B. (2008) Effects of temperature on photosynthetic parameters and TEP production in eight species of marine microalgae. Aquatic Microbial Ecology 51, $1-11$.

Cole J.J., Likens G.E. \& Strayer D.L. (1982) Photosynthetically produced dissolved organic carbon: an important carbon source for planktonic bacteria [Mirror Lake, New Hampshire, algae]. Limnol. Oceanogr 27, 1080-1090.

Costas E., López-Rodas V., Toro F.J. \& Flores-Moya A. (2008) The number of cells in colonies of the cyanobacterium Microcystis aeruginosa satisfies Benford's law. Aquatic Botany 89, 341-343.

Croft M.T., Lawrence A.D., Raux-Deery E., Warren M.J. \& Smith A.G. (2005) Algae acquire vitamin 530 B12 through a symbiotic relationship with bacteria. Nature 438, 90-93.

531 Danger M., Leflaive J., Oumarou C., Ten-Hage L. \& Lacroix G. (2007) Control of 532 phytoplankton?bacteria interactions by stoichiometric constraints. Oikos 116, 1079-1086.

533 Danger M., Oumarou C., Benest D. \& Lacroix G. (2007) Bacteria can control stoichiometry and 534 nutrient limitation of phytoplankton. Functional Ecology 21, 202-210.

Decho A.W. \& Lopez G.R. (1993) Exopolymer microenvironments of microbial flora: multiple and interactive effects on trophic relationships. Limnol. Oceanogr 38, 1633-1645.

537 De Philippis R., Sili C. \& Vincenzini M. (1996) Response of an exopolysaccharide-producing 538 heterocystous cyanobacterium to changes in metabolic carbon flux. Journal of Applied Phycology. 8 : $539275-281$.

540 De Philippis R. \& Vincenzini M. (1998) Exocellular polysaccharides from cyanobacteria and their 541 possible applications. FEMS Microbiology Reviews 22, 151-175.

542 Dubois M., Gilles K., Hamilton J.K., Rebers P.A. \& Smith F. (1956) A colorimetric method for the determination of sugars. Nature, 28: 350-356.

544 Dutz J., Klein Breteler W.C.M. \& Kramer G. (2005) Inhibition of copepod feeding by exudates and 545 transparent exopolymer particles (TEP) derived from a Phaeocystis globosa dominated phytoplankton 546 community. Harmful Algae 4, 929-940.

547 Eilers P. \& Peeters J. (1988) A model for the relationship between light intensity and the rate of 548 photosynthesis in phytoplankton. Ecological Modelling. 42, 199-215

549 Engel A. \& Passow U. (2001) Carbon and nitrogen content of transparent exopolymer particles (TEP) 550 in relation to their Alcian Blue adsorption. Marine Ecology Progress Series 219, 1-10.

551 Engel A., Delille B., Jacquet S., Riebesell U., Rochelle-Newall E., Terbruggen A., et al. (2004) 552 Transparent exopolymer particles and dissolved organic carbon production by Emiliania huxleyi exposed to different $\mathrm{CO} 2$ concentrations: a mesocosm experiment. Aquatic Microbial Ecology 34, 93104.

555 Fagerbakke K.M., Heldal M. \& Norland S. (1996) Content of carbon, nitrogen, oxygen, sulfur and 556 phosphorus in native aquatic and cultured bacteria. Aquatic Microbial Ecology 10, 15-27.

557 Flemming H.-C. \& Wingender J. (2010) The biofilm matrix. Nature Reviews, Microbiology, 8, 623558633.

559 Gärdes A., Ramaye Y., Grossart H.P., Passow U. \& Ullrich M.S. (2012) Effects of Marinobacter 560 adhaerens HP15 on polymer exudation by Thalassiosira weissflogii at different N:P ratios. Marine 561 Ecology Progress Series 461, 1-14.

562 Gilbert M., Wilhelm C. \& Richter M. (2000) Bio-optical modelling of oxygen evolution using in vivo 563 fluorescence: Comparison of measured and calculated photosynthesis/irradiance (P-I) curves in four 564 representative phytoplankton species. Journal of Plant Physiology 157, 307-314. 
Grossart H.P., Simon M. \& Logan B.E. (1997) Formation of macroscopic organic aggregates (lake snow) in a large lake: The significance of transparent exopolymer particles, phytoplankton, and zooplankton. Limnol. Oceanogr 42, 1651-1659.

568 Hessen D.O. (1992) Nutrient element limitation of zooplankton production, The American Naturalist, 569 140, 799-814.

Hessen D.O. \& Anderson T.R. (2008) Excess carbon in aquatic organisms and ecosystems: physiological, ecological, and evolutionary implications. Limnol. Oceanogr 53, 1685-1696.

Huisman J., Matthijs H.C.P. \& Visser P.M. eds (2005) Harmful cyanobacteria. Springer, Kluwer,

\section{Dordrecht.}

574 Jensen T.C. \& Verschoor A.M. (2004) Effects of food quality on life history of the rotifer Brachionus calyciflorus Pallas. Freshwater Biology 49, 1138-1151.

Johnk K.D., Huisman J., Sharples J., Sommeijer B.P., Visser P.M. \& Stroom J.M. (2008) Summer heatwaves promote blooms of harmful cyanobacteria. Global Change Biology 14, 495-512.

Klausmeier C.A., Litchman E. \& Levin S.A. (2004) Phytoplankton growth and stoichiometry under multiple nutrient limitation. Limnol. Oceanogr 49, 1463-1470.

580 Kromkamp J. (1987) Formation and functional significance of storage products in cyanobacteria. New 581 Zealand Journal of Marine and Freshwater Research 21, 457-465.

582 Kromkamp J.C. \& Forster R.M. (2003) The use of variable fluorescence measurements in aquatic ecosystems: differences between multiple and single turnover measuring protocols and suggested terminology. European Journal of Phycology 38, 103-112.

Ling S.C. \& Alldredge A.L. (2003) Does the marine copepod Calanus pacificus consume transparent exopolymer particles (TEP)? Journal of Plankton Research 25, 507-515.

Liu H. \& Buskey E.J. (2000) Hypersalinity enhances the production of extracellular polymeric substance (EPS) in the texas brown tide alga, Aureoumbra lagunensis (Pelagophyceae). Journal of

589 Phycol., 36, 71-77.

López-Sandoval D.C., Rodríguez-Ramos T., Cermeno P. \& Marañón E. (2013) Exudation of organic carbon by marine phytoplankton: dependence on taxon and cell size. Marine Ecology Progress Series 477, 53-60.

Marañón E., Cermeño P., López-Sandoval D.C., Rodríguez-Ramos T., Sobrino C., Huete-Ortega M., et al. (2013) Unimodal size scaling of phytoplankton growth and the size dependence of nutrient uptake and use. Ecology Letters 16, 371-379.

Mari X. \& Kiørboe T. (1996) Abundance, size distribution and bacterial colonization of transparent exopolymeric particles (TEP) during spring in the Kattegat. Journal of Plankton Research, 18, 969986.

Mari X., Beauvais S., Lemée R. \& Pedrotti M.L. (2001) Non-Redfield C: N ratio of transparent exopolymeric particles in the northwestern Mediterranean Sea. Limnol. Oceanogr 46, 1831-1836.

Myklestad S.M. (1995) Release of extracellular products by phytoplankton with special emphasis on polysaccharides. Science of the Total Environment, 165, 155-164.

Oksanen J. (2013) Multivariate Analysis of Ecological Communities in R: vegan tutorial. R package version, $1-43$.

Passow U. (2002) Transparent exopolymer particles (TEP) in aquatic environments. Progress in

607 Passow U. \& Alldredge A.L. (1995) Aggregation of a diatom bloom in a mesocosm: The role of 608 transparent exopolymer particles (TEP). Deep-Sea Research Part II 42, 99-109.

609 Passow U. \& Alldredge A.L. (1999) Do transparent exopolymer particles (TEP) inhibit grazing by the 
Post AF, deWit R, Mur LR (1985) Interaction between temper- ature and light intensity on growth and photosynthesis of the cyanobacterium Oscillatoria agardhii. J Plankton Res 7:487 - 495

613 R Development Core Team R. (2011) R: a language and environment for statistical computing. R 614 Foundation for Statistical Computing, Vienna, Austria.

Redfield C.A., Ketchum H.B. \& Richards A.F. (1963) The influence of organisms on the composition of sea-water. In: The composition of seawater. Comparative and descriptive oceanography. The sea: ideas and observations on progress in the study of the seas. (Ed. H. NM), pp. 26-77. New York.

618 Reynolds C.S. (2006) The Ecology of Phytoplankton. Ecology, Biodiversity and Conservation.

619 Cambridge.

620 Reynolds C.S. (2007) Variability in the provision and function of mucilage in phytoplankton:

621 facultative responses to the environment. Hydrobiologia 578, 37-45.

622 Reynolds C.S., Huszar V., Kruk C., Naselli-Flores L. \& Melo S. (2002) Towards a functional

623 classification of the freshwater phytoplankton. Journal of Plankton Research 24, 417-428.

624 Rippka R. (1988) Isolation and purification of cyanobacteria. Methods in enzymology 167, 3-27.

625 Rohrlack, T., G. Christiansen, and R. Kurmayer. (2013) Putative antiparasite defensive system 626 involving ribosomal and nonribosomal oligopeptides in cyanobacteria of the genus Planktothrix. Appl. 627 Environ. Microbiol. 79: 2642-2647, doi:10.1128/AEM.03499-12

628 Schreiber U. (1998) Chlorophyll fluorescence: new instruments for special applications.

629 Photosynthesis: mechanisms and effects 5, 4253-4258.

630 Shen H., Niu Y., Xie P., Tao M. \& Yang X.I. (2011) Morphological and physiological changes in 631 Microcystis aeruginosa as a result of interactions with heterotrophic bacteria. Freshwater Biology 56, $632 \quad 1065-1080$.

633 Shibata K., Benson A.A. \& Calvin M. (1954) The absorption spectra of suspensions of living micro634 organisms. Biochimica et biophysica acta 15, 461-470.

635 Simon M., Grossart H.-P., Schweitzer B. \& Ploug H. (2002) Microbial ecology of organic aggregates 636 in aquatic ecosystems. Aquatic Microbial Ecology 28, 175-211.

637 Staats N., De Winder B., Stal L. \& Mur L. (1999) Isolation and characterization of extracellular 638 polysaccharides from the epipelic diatoms Cylindrotheca closteriumand Navicula salinarum. 639 European Journal of Phycology 34, 161-169.

640 Sterner R.W. \& Elser J.J. (2002) Ecological Stoichiometry: The Biology of Elements from Molecules 641 to the biosphere - Princeton University Press, Oxfordshire.

642 Sugiura N. (1978) Further analysts of the data by akaike's information criterion and the finite 643 corrections. Communications in Statistics - Theory and Methods 7, 13-26.

644 Svane R and Eriksen NT (2015). Exopolysaccharides are partly growth associated products in 645 Microcystis flos-aquae. J Appl Phycol. 27 :163-170.

646 Thornton D.C.O. (2002) Diatom aggregation in the sea: mechanisms and ecological implications. 647 European Journal of Phycology 37, 149-161.

648 Underwood G., Paterson D.M. \& Parkes R.J. (1995) The measurement of microbial carbohydrate 649 exopolymers from intertidal sediments. Limnol. Oceanogr 40, 1243-1253.

650 Underwood G.J.C., Boulcott M., Raines C.A. \& Waldron K. (2004) Environmental effects on 651 exopolymer production by marine benthic diatoms: dynamics, changes in composition and pathways 652 of production. Journal of Phycology 40, 293-304.

653 Urabe J., Togari J. \& Elser J.J. (2003) Stoichiometric impacts of increased carbon dioxide on a 654 planktonic herbivore. Global Change Biology 9, 818-825. 
Van de Waal D.B., Verschoor A.M., Verspagen J.M., Van Donk E. \& Huisman J. (2010) Climate656 driven changes in the ecological stoichiometry of aquatic ecosystems. Frontiers in Ecology and the 657 Environment 8, 145-152.

658 Verdugo P., Alldredge A.L., Azam F., Kirchman D.L., Passow U. \& Santschi P.H. (2004) The oceanic 659 gel phase: a bridge in the DOM-POM continuum. Marine Chemistry 92, 67-85.

660 Vieira A.A.H., Ortolano P.I.C., Giroldo D., Oliveira M.J.D., Bittar T.B., Lombardi A.T., et al. (2008)

661 Role of hydrophobic extracellular polysaccharide of Aulacoseira granulata (Bacillariophyceae) on 662 aggregate formation in a turbulent and hypereutrophic reservoir. Limnol. Oceanogr, 53, 1887-1899.

663 Worm J. \& Søndergaard M. (1998) Alcian blue-stained particles in a eutrophic lake. Journal of 664 Plankton Research 20, 179-186.

665 Yallop M.L., Paterson D.M. \& Wellsbury P. (2000) Interrelationships between Rates of Microbial 666 Production, Exopolymer Production, Microbial Biomass, and Sediment Stability in Biofilms of 667 Intertidal Sediments. Microbial Ecology 39, 116-127.

668 Yéprémian, C., Gugger, M.F., Briand, E., Catherine, A., Berger, C., Quiblier, C., Bernard, C. (2007) 669 Microcystin ecotypes in a perennial Planktothrix agardhii bloom. Water Res. 41, 4446-4456.

670 Zhang M., Shi X., Yu Y. \& Kong F. (2011) The acclimative changes in photochemistry after colony 671 formation of the cyanobacteria Microcystis aeruginosa. Journal of Phycology 47, 524-532. 
675 Table 1: origin and morphological characteristics of the five species of cyanobacteria:

Table 2: Parameter estimates for the best model predicting the TEP production in M. aeruginosa, as determined by a stepwise selection of the variables using the AIC criterion. The initial model includes

678 the maximum electron transport rate, the concentration of nitrates in the medium, the presence of $\mathrm{HB}$

679 (included as a qualitative factor), and the interaction between nitrates and HB. Result from its

680 ANOVA is also shown. Significance levels are coded as follow: ' $* * *$ ' indicates $<0.001,{ }^{\prime} * *{ }^{\prime}<0.01$, 681 and ' $*$ ' $<0.05$.

682 Table 3: Parameter estimates for the best model predicting the $\mathrm{C}: \mathrm{N}$ ratio in M. aeruginosa, as 683 determined by a stepwise selection of the variables using the AIC criterion. Result from its ANOVA is 684 also shown. Significance levels are coded as follow: '***' indicates $<0.001$, '**' $<0.01$, and '*' $<0.05$.

686 Figure 1: Maximum electron transport rate (ETRmax) of M. aeruginosa, during exponential growth (white area) and stationary phase (grey area), depending on the presence of heterotrophic bacteria and nitrate availability: $A x$ : Axenic, $B$ : associated with bacteria, $+N$ : high level of $\mathrm{N}$ availability, $-N$ : low level of $\mathrm{N}$ availability. Means of replicate value ( \pm standard deviation) are shown. No statistical difference based on Wilcoxon rank-sum test and Tukey post hoc test $(\mathrm{P}>0.05)$.

691 Figure 2: (A) TEP and (B) S-EPS produced by M. aeruginosa, during exponential growth (white area) and stationary phase (grey area), depending on the presence of heterotrophic bacteria and nitrate availability: $A x$ : Axenic, $B$ : associated with bacteria, $+N$ : high level of $\mathrm{N}$ availability, $-N$ : low level of $\mathrm{N}$ availability. Means of replicate value ( \pm standard deviation) are shown. $\mathrm{a} \neq \mathrm{b}$ and $\mathrm{c} \neq \mathrm{d}$ based on Wilcoxon rank-sum test and Tukey post hoc test $(\mathrm{P}<0.05)$.

696 Figure 3: (A) Molar C:N and (B) C:P ratios of M. aeruginosa (axenic condition shown by open diamonds) and of the cyanobacteria associated with heterotrophic bacteria (filled circles) depending on the amount of TEP per cyanobacterial cell. Correlations in axenic condition and in the presence of $\mathrm{HB}$ (including both $+\mathrm{N}$ and $-\mathrm{N}$ ) are shown.

700 Figure 4: Time series of the biomass absorbance (means of replicate value), expressed as Chlorophyll

701 a concentration, of the cyanobacteria species.

702 Figure 5: The maximum electron transport rate (ETRmax) measured during exponential growth (white 703 area) and the early stationary phase (grey area), depending on cyanobacterial species. Means of 704 replicate value ( \pm standard deviation) are shown. $\mathrm{a} \neq \mathrm{b}$ and $\mathrm{c} \neq \mathrm{d}$ based on Wilcoxon rank-sum test and 705 Tukey post hoc test $(\mathrm{P}<0.05)$. 
706 Figure 6: Boxplot of (A) the mean concentration of S-EPS in the culture per unit of cell volume ( $\mu \mathrm{g}$

707 ep. $\mathrm{C} \mathrm{mm}^{3}$ ) depending on cyanobacteria, of (B) the TEP per unit of cell volume ( $\mu \mathrm{g}$ ep. $\mathrm{C} \mathrm{mm}^{3}$ ), of (C)

708 the molar $\mathrm{C}: \mathrm{N}$ ratio and (D) $\mathrm{C}: \mathrm{P}$ of the particulate organic matter. $\mathrm{C}$ represents the Chroococcales and

$709 \mathrm{O}$ the Oscillatoriales. $\mathrm{a} \neq \mathrm{b} \neq \mathrm{c}$ based on Wilcoxon rank-sum test and Tukey post hoc test $(\mathrm{P}<0.05)$.

710 Figure 7: (a) C content, (b) $\mathrm{N}$ content and (c) P content per cyanobacterial cell of the particulate

711 organic matter depending on the TEP concentration per cyanobacterial cell, considering the five

712 species. Data correspond to the three replicates measured during the exponential phase (open symbols)

713 and during the early stationary phase (black symbols). Regressions refer to the entire set of data

714 points.

715 Figure 8: molar $\mathrm{C}: \mathrm{N}$ ratio of the particulate organic matter depending on the S-EPS concentration in

716 the medium, considering the five species. Data correspond to the three replicates measured during the

717 exponential phase (open symbols) and during the early stationary phase (black symbols). Regression

718 refers to the entire set of points.

719 Figure 9: Redundancy analysis (RDA) triplots for the molar C:N and N:P ratios, the TEP and S-EPS

720 per cyanobacterial cell ( $\mu \mathrm{g}$ eq $\mathrm{C} \mathrm{cell}^{-1}$ ) of the five cyanobacteria, explained by the growth rate, the cell

721 ratio surface:volume of the species, and the nitrates and the phosphates concentrations in the medium.

722 Exponential E growth phase (o) and stationary S phase ( $\square$ ) are shown, with the three replicates. 
723 Table 1: origin and morphological characteristics of the five species of cyanobacteria:

\begin{tabular}{cccccc}
\hline Genus & Species & Origin & Form & $\mathbf{V}\left(\mathbf{\mu m}^{\mathbf{3}}\right)$ & $\mathbf{S} / \mathbf{V}$ \\
\hline Microcystis & aeruginosa PCC7806 & Pasteur institute & Sphere & 33.5 & 1500 \\
\hline Aphanothece & clathrata $($ TCC 4a) & $\begin{array}{c}\text { INRA UMR } \\
\text { CARRTEL }\end{array}$ & Prolate spheroid & 8.4 & 633 \\
\hline Aphanothece & minutissima (TCC 323) & $\begin{array}{c}\text { INRA UMR } \\
\text { CARRTEL }\end{array}$ & Prolate spheroid & 8.4 & 633 \\
\hline Limnothrix & (LRP29) & UMR 6553 & Filamentous & 8.2 & 2 \\
\hline Planktothrix & agardhii & UMR 6553 & Filamentous & 84.8 & 2 \\
\hline
\end{tabular}

724

725 
725 Table 2: Parameter estimates for the best model predicting the TEP production in M. aeruginosa, as

726 determined by a stepwise selection of the variables using the AIC criterion. The initial model includes

727 the maximum electron transport rate, the concentration of nitrates in the medium, the presence of HB

728 (included as a qualitative factor), and the interaction between nitrates and HB. Result from its

729 ANOVA is also shown. Significance levels are coded as follow: '***' indicates $<0.001$, '**' $<0.01$,

$730 \quad$ and '*' $<0.05$.

\begin{tabular}{cccccccc}
\hline & Estimate & Std. & Sum of sq & Df & F value & Proba $(>\mathrm{F})$ & \\
\hline (Intercept) & 2.86 & 0.26 & & & & & \\
NO3 & -0.01 & 0.01 & 0.087 & 1 & 0.43 & 0.52 \\
bacteria & -0.16 & 0.24 & 0.19 & 1 & 0.97 & 0.34 \\
ETRmax & -0.84 & 0.30 & 1.59 & 1 & 7.93 & 0.011 & $*$ \\
interaction NO3 x bacteria & 0.042 & 0.02 & 0.92 & 1 & 4.58 & 0.045 & $*$ \\
Residuals & & & 3.81 & 19 & & & \\
\hline
\end{tabular}

731 Model statistics: $\mathrm{AIC}=-34.12$, Residual standard error: $0.448, \mathrm{DF}=19, \mathrm{R}^{2}=0.42, \mathrm{p}=0.027$. 
732 Table 3: Parameter estimates for the best model predicting the C:N ratio in M. aeruginosa, as

733 determined by a stepwise selection of the variables using the AIC criterion. Result from its ANOVA is

734 also shown. Significance levels are coded as follow: '***' indicates $<0.001$, '**' $<0.01$, and ' $*$ ' $<0.05$.

\begin{tabular}{cccccccc}
\hline & Estimate & Std. & Sum of sq & Df & F value & Proba $(>\mathrm{F})$ & \\
\hline (Intercept) & 4.96 & 2.98 & & & & & \\
TEP & 5.73 & 1.23 & 292 & 1 & 55.99 & $<0.0001$ & $* * *$ \\
NO3 & -0.11 & 0.07 & 114 & 1 & 21.77 & 0.0002 & $* * *$ \\
bacteria & -11.28 & 4.76 & 67 & 1 & 12.76 & 0.002 & $* *$ \\
interaction TEP x bacteria & 4.44 & 2.04 & 25 & 1 & 4.74 & 0.043 & $*$ \\
interaction NO3 x bacteria & -0.27 & 0.11 & 35 & 1 & 6.67 & 0.019 & $*$ \\
Residuals & & & 94 & 18 & & & \\
\hline
\end{tabular}


741 Figure 1: Maximum electron transport rate (ETRmax) of M. aeruginosa, during exponential growth

742 (white area) and stationary phase (grey area), depending on the presence of heterotrophic bacteria and

743 nitrate availability: $A x$ : Axenic, $B$ : associated with bacteria, $+N$ : high level of $\mathrm{N}$ availability, $-N$ : low

744 level of $N$ availability. Means of replicate value ( \pm standard deviation) are shown. No statistical

745 difference based on Wilcoxon rank-sum test and Tukey post hoc test $(\mathrm{P}>0.05)$.

746

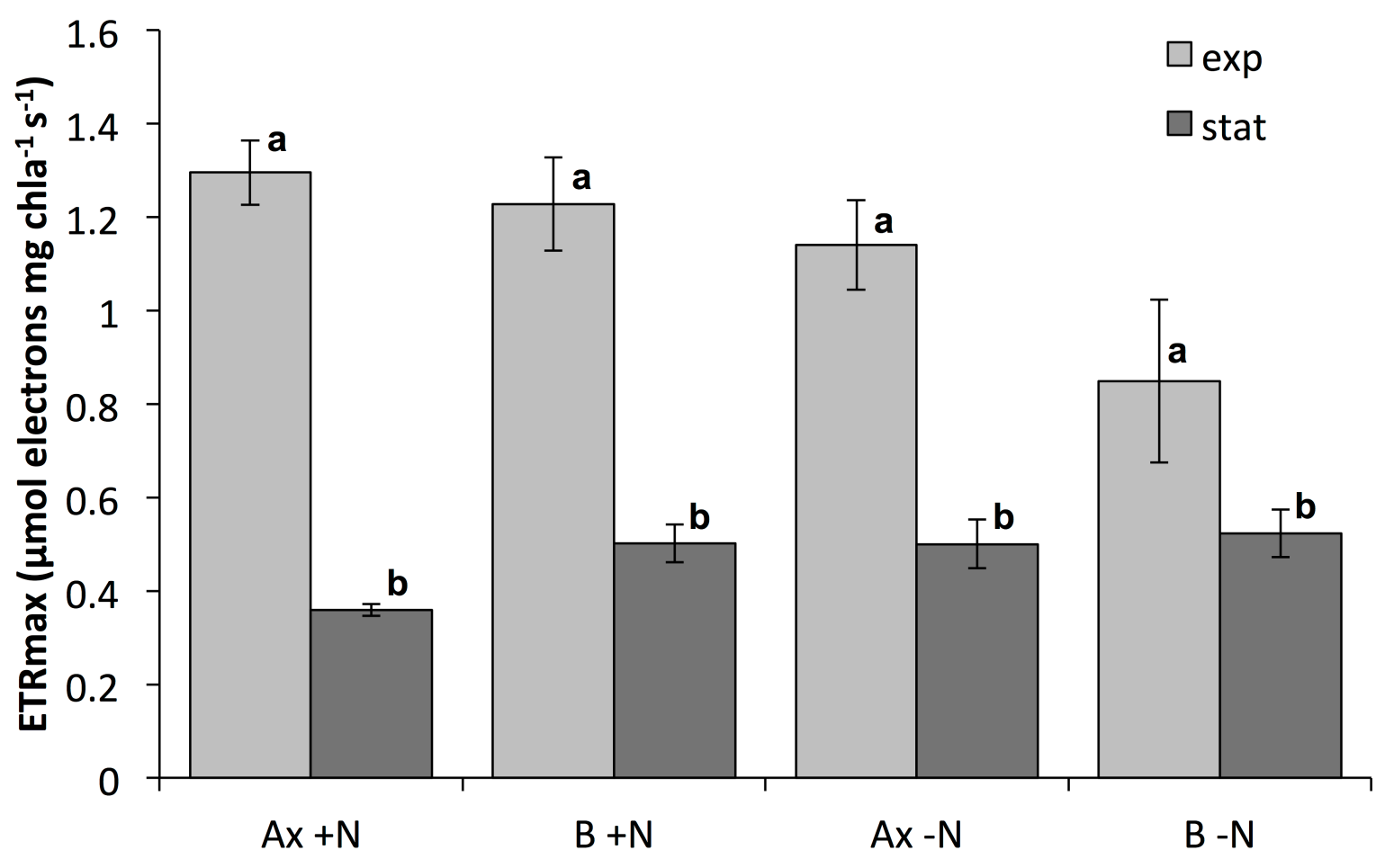


Figure 2: (A) TEP and (B) S-EPS produced by M. aeruginosa, during exponential growth (white area)
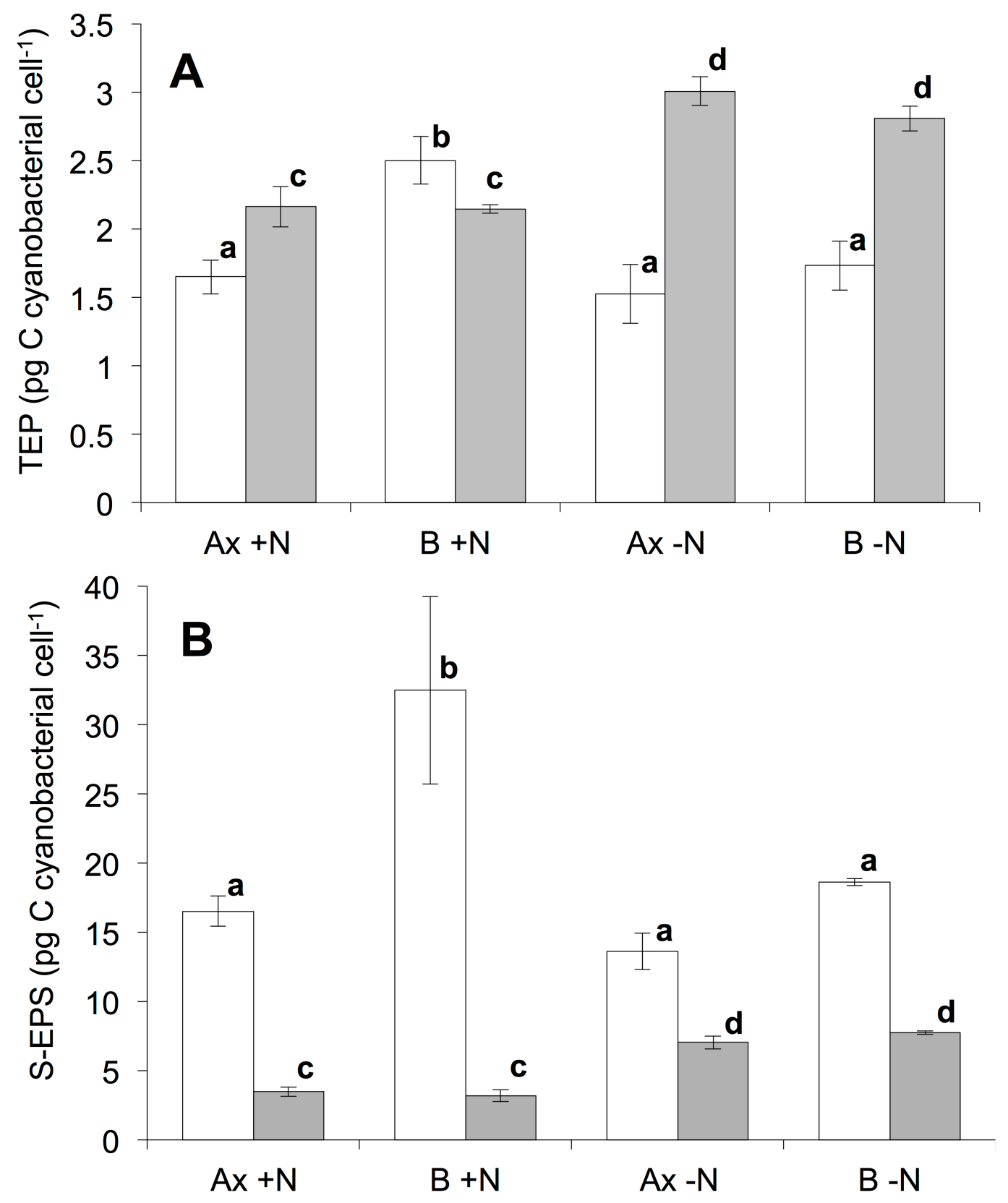
Figure 3: (A) Molar C:N and (B) C:P ratios of M. aeruginosa (axenic condition shown by open diamonds) and of the cyanobacteria associated with heterotrophic bacteria (filled circles) depending on the amount of TEP per cyanobacterial cell. Correlations in axenic condition and in the presence of $\mathrm{HB}$ (including both $+\mathrm{N}$ and $-\mathrm{N}$ ) are shown.

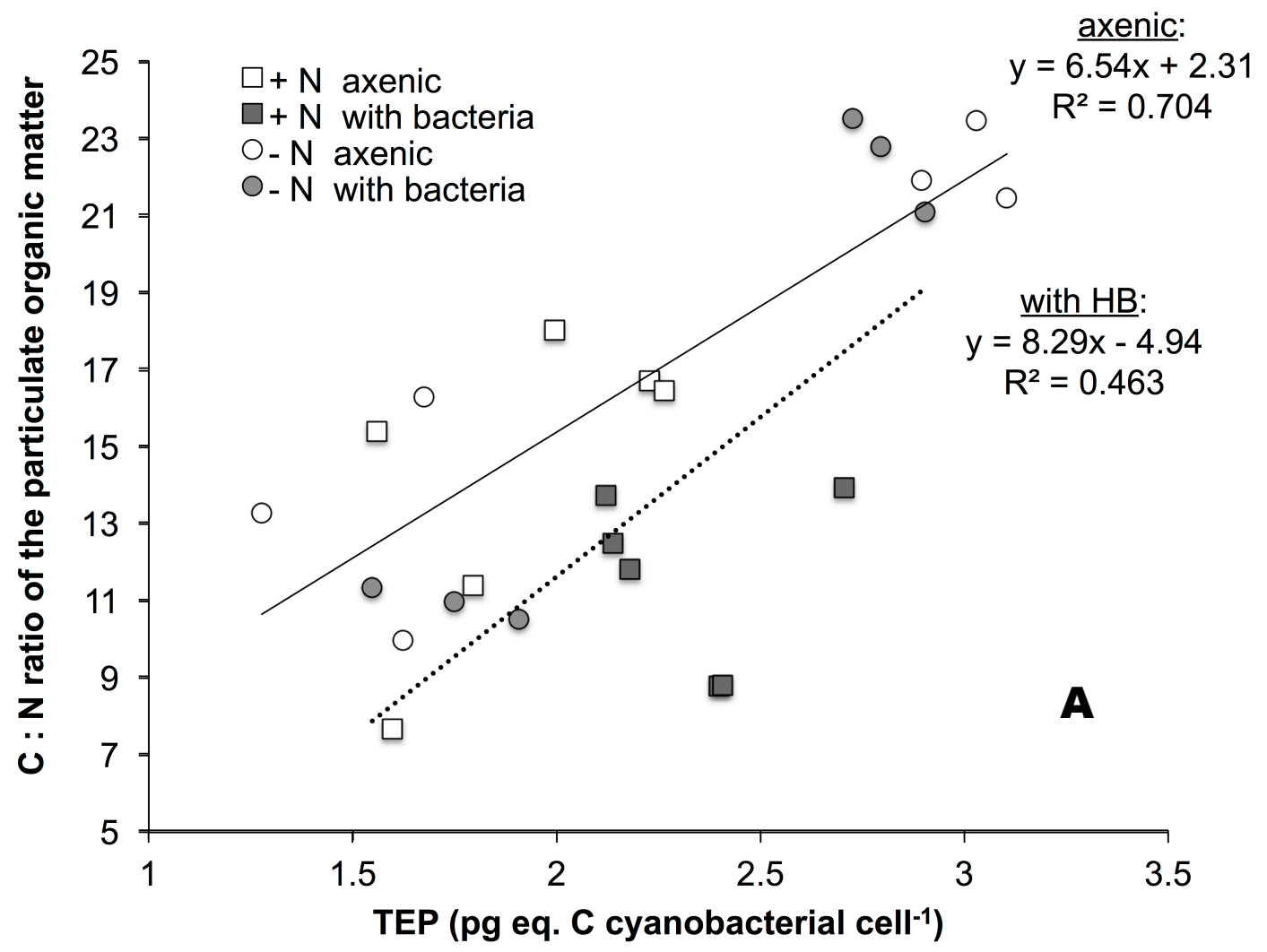

761

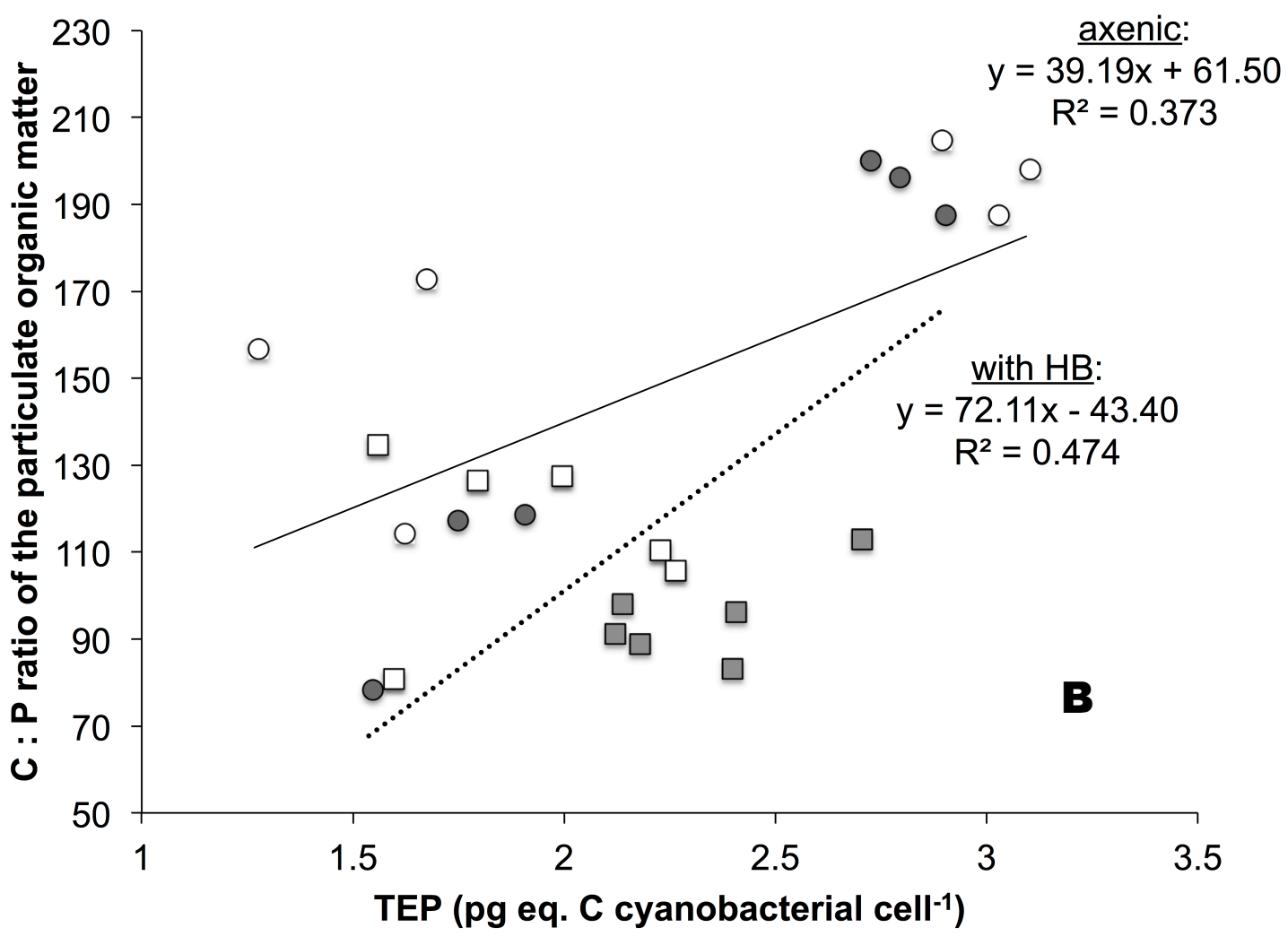



a concentration, of the cyanobacteria species.

765

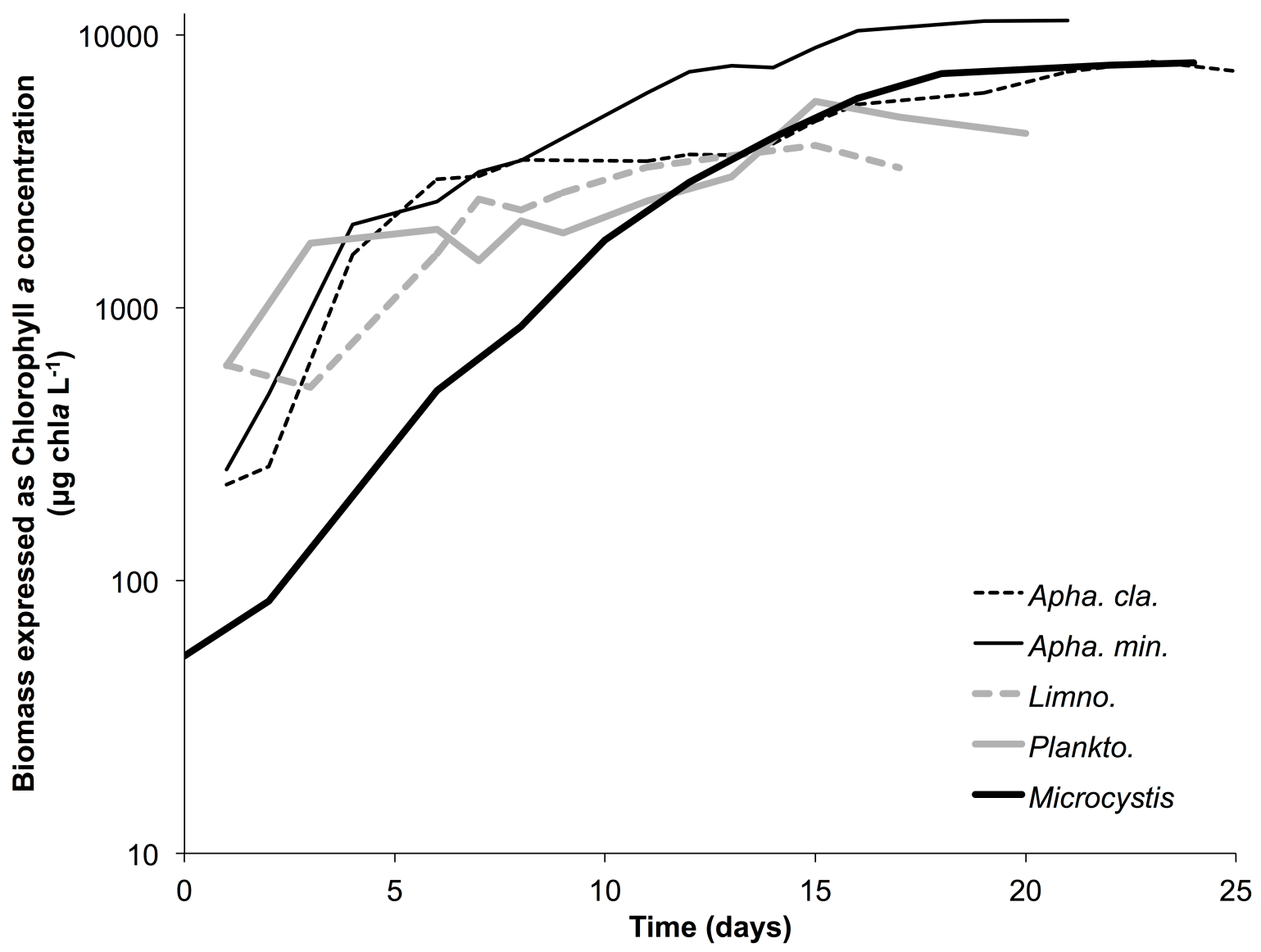

766

767

768 
Figure 5: The maximum electron transport rate (ETRmax) measured during exponential growth (white area) and the early stationary phase (grey area), depending on cyanobacterial species. Means of replicate value ( \pm standard deviation) are shown. $\mathrm{a} \neq \mathrm{b}$ and $\mathrm{c} \neq \mathrm{d}$ based on Wilcoxon rank-sum test and

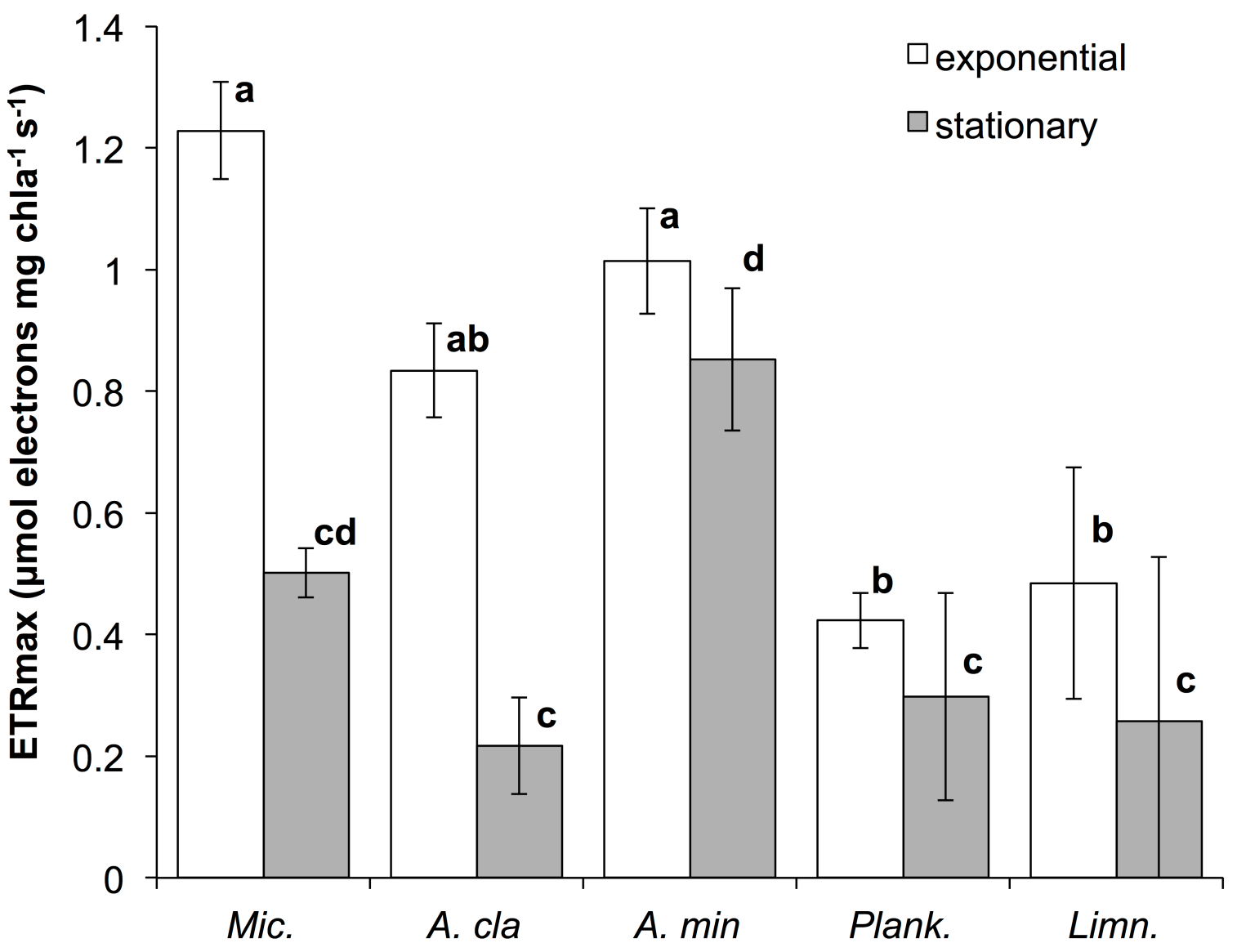


Figure 6: Boxplot of (A) the mean concentration of S-EPS in the culture per unit of cell volume ( $\mu \mathrm{g}$ ep. $\mathrm{C} \mathrm{mm}^{3}$ ) depending on cyanobacteria, of (B) the TEP per unit of cell volume ( $\mu \mathrm{g}$ ep. $\mathrm{C} \mathrm{mm}^{3}$ ), of (C)

779 the molar $\mathrm{C}: \mathrm{N}$ ratio and (D) $\mathrm{C}: \mathrm{P}$ of the particulate organic matter. $\mathrm{C}$ represents the Chroococcales and $780 \quad \mathrm{O}$ the Oscillatoriales. $\mathrm{a} \neq \mathrm{b} \neq \mathrm{c}$ based on Wilcoxon rank-sum test and Tukey post hoc test $(\mathrm{P}<0.05)$.

781
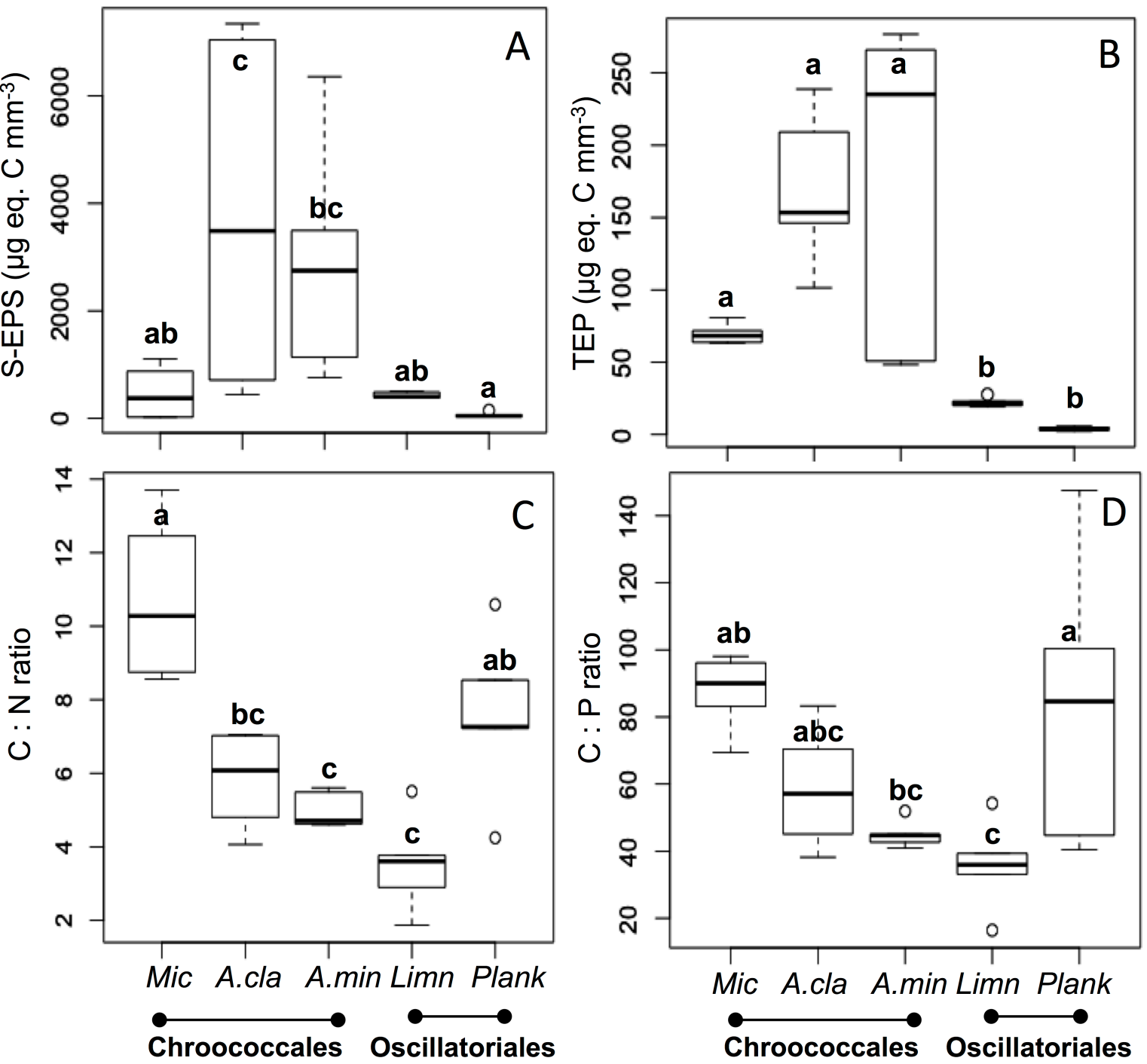
Figure 7: (a) $\mathrm{C}$ content, (b) $\mathrm{N}$ content and (c) $\mathrm{P}$ content per cyanobacterial cell of the particulate species. Data correspond to the three replicates measured during the exponential phase (open symbols) and during the early stationary phase (black symbols). Regressions refer to the entire set of data
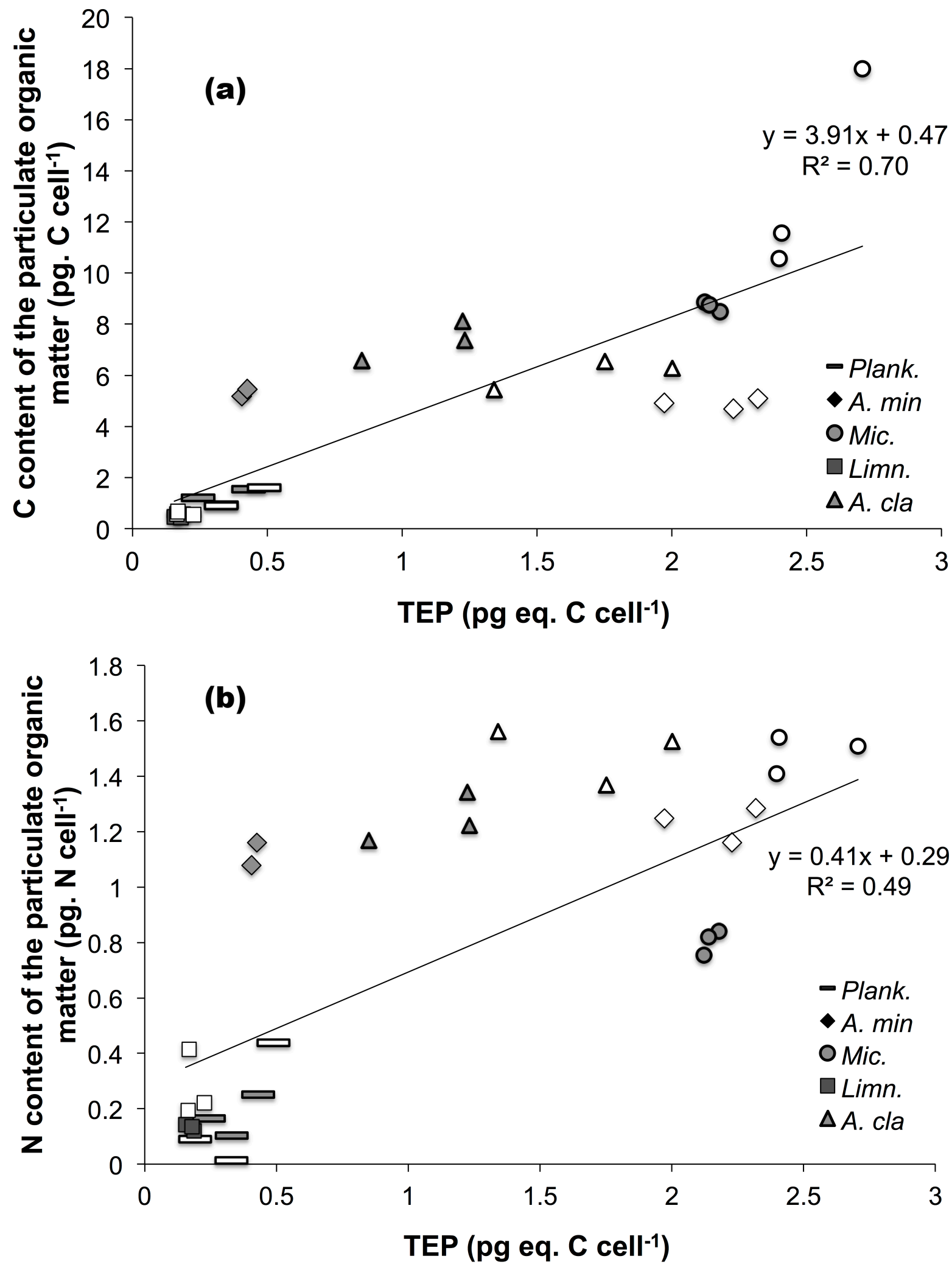


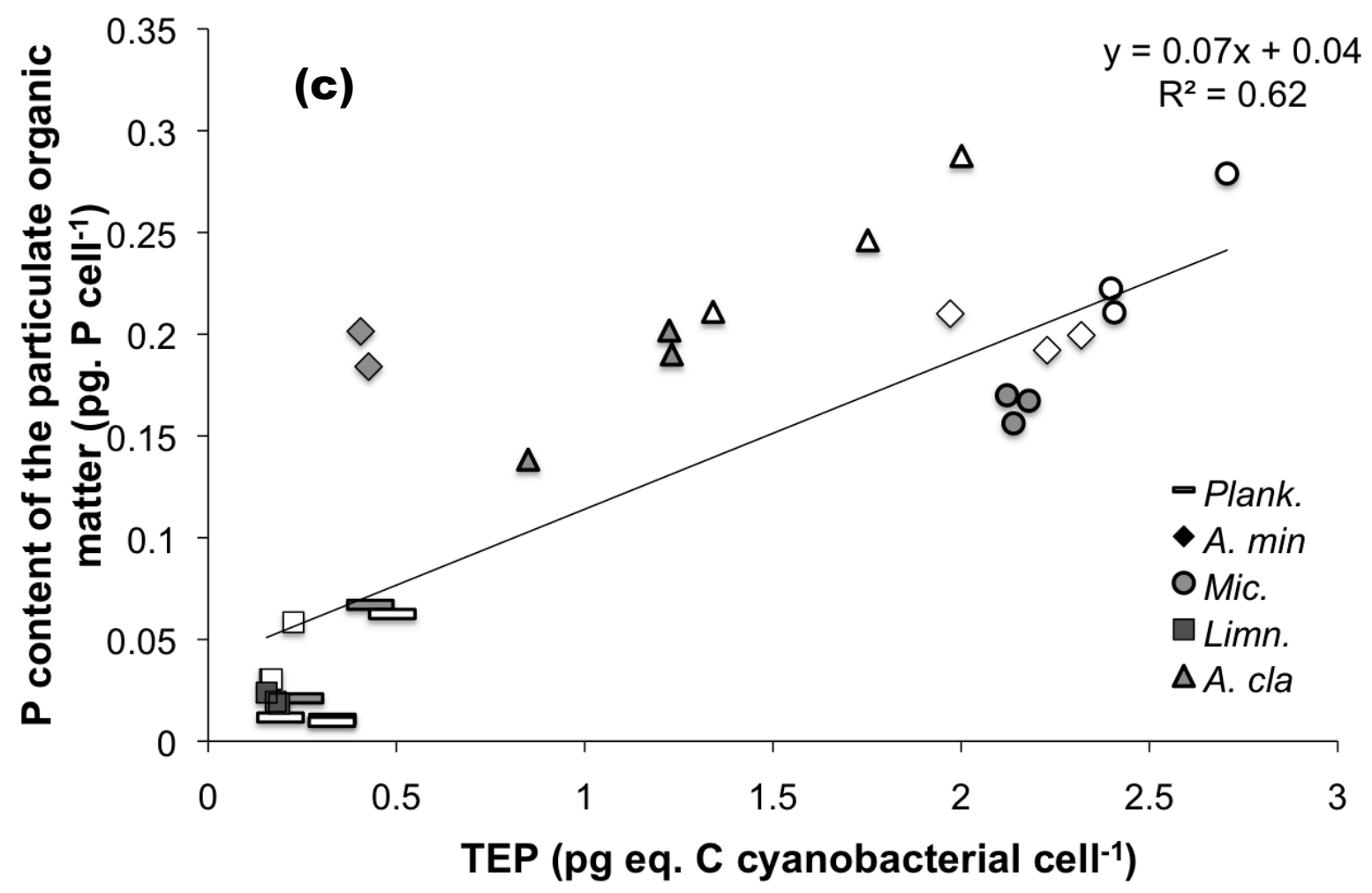

790
791 
791 Figure 8: molar $\mathrm{C}: \mathrm{N}$ ratio of the particulate organic matter depending on the S-EPS concentration in

792 the medium, considering the five species. Data correspond to the three replicates measured during the 793 exponential phase (open symbols) and during the early stationary phase (black symbols). Regression 794 refers to the entire set of points.

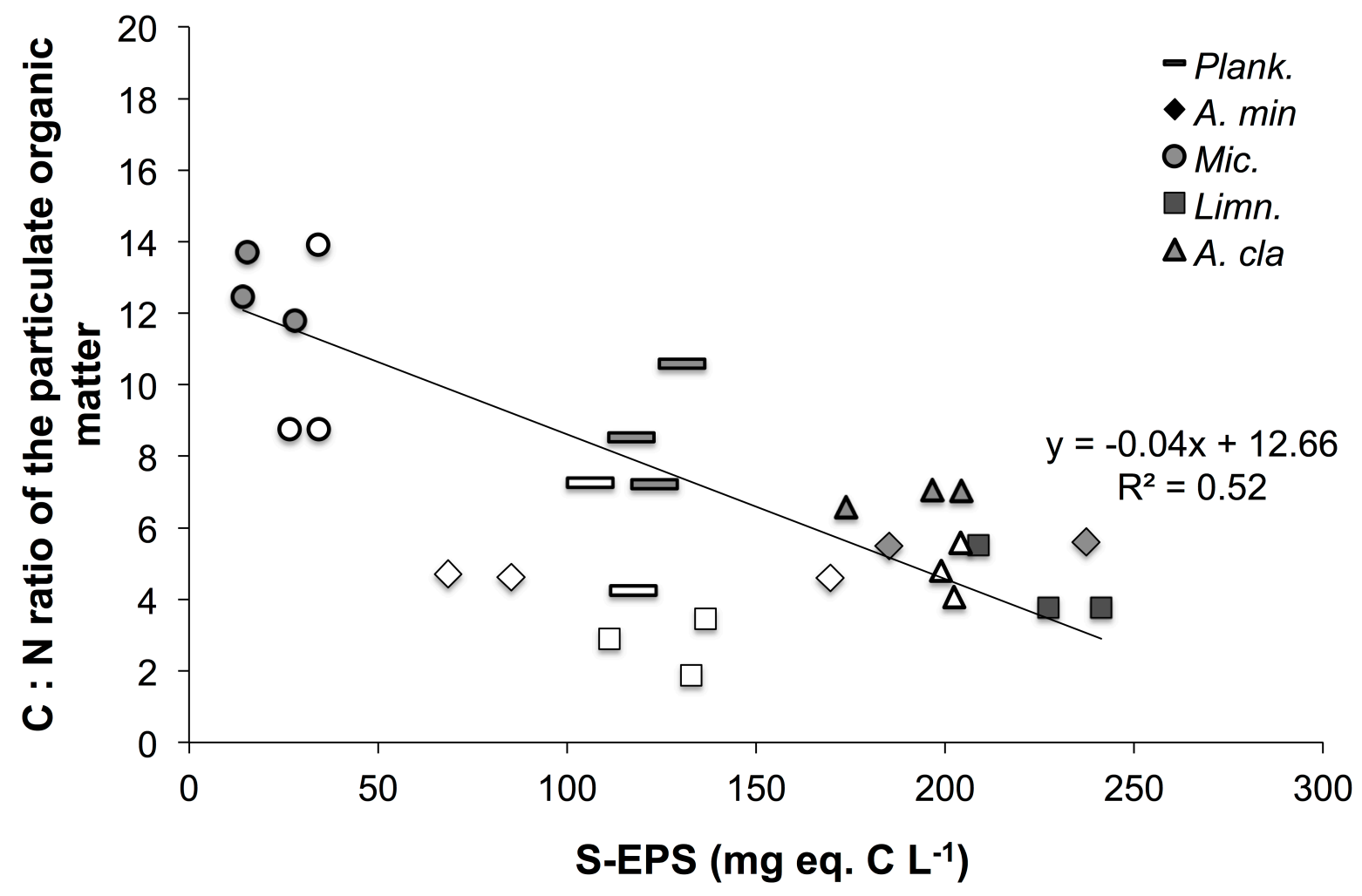


Figure 9: Redundancy analysis (RDA) triplots for the molar C:N and N:P ratios, the TEP and S-EPS

797 per cyanobacterial cell ( $\mu \mathrm{g}$ eq $\mathrm{C} \mathrm{cell}^{-1}$ ) of the five cyanobacteria, explained by the growth rate, the cell

798 ratio surface:volume of the species, and the nitrates and the phosphates concentrations in the medium.

799 Exponential E growth phase (o) and stationary S phase ( $\square$ ) are shown, with the three replicates.

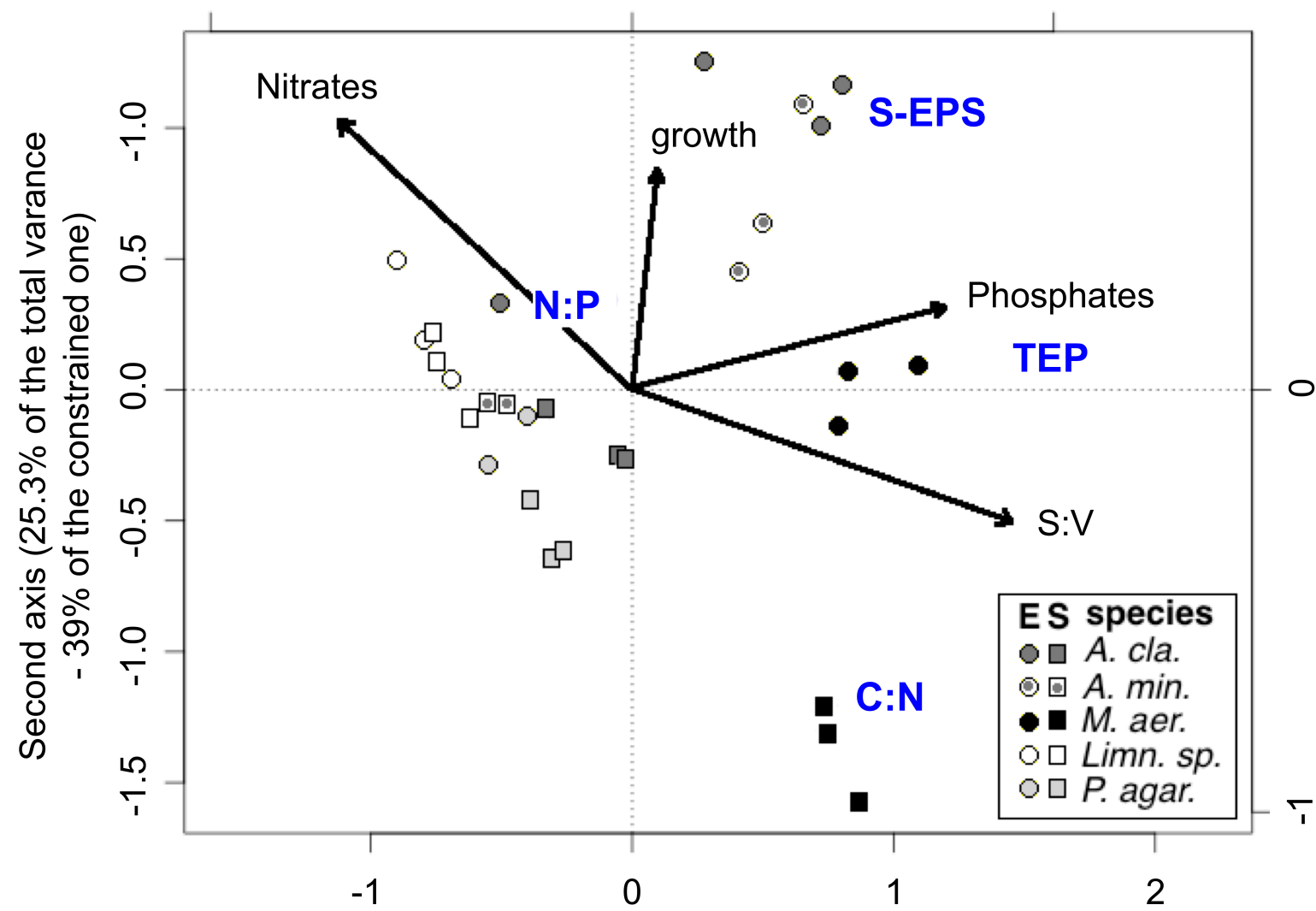


802 Additional Supporting Information may be found in the online version of this article:

803 Fig. S1. Absorbance measured at $680 \mathrm{~nm}$ as a function of the absorbance measured at $750 \mathrm{~nm}$ 804 for Microcystis cultures, in axenic condition (blue diamonds) and in the presence of 805 heterotrophic bacteria (red squares).

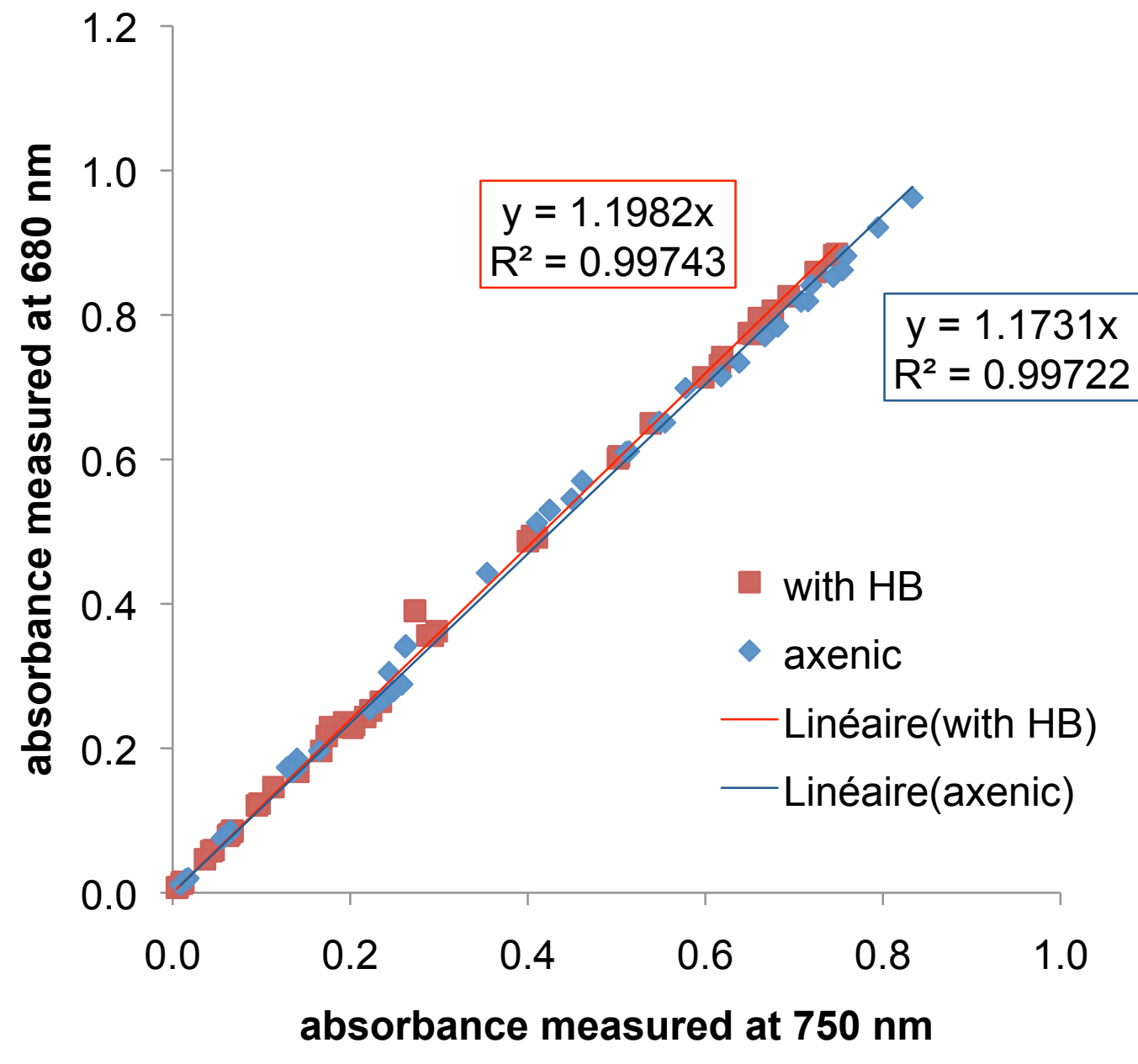

806

807 Table S1: Parameter estimates for the best model predicting the C:P ratio in M. aeruginosa, 808 as determined by a stepwise selection of the variables using the AIC criterion. Result from its 809 ANOVA is also shown. Significance levels are coded as follow: '***' indicates $<0.001$, ' $* *$ ' $<0.01$, and ' $*$ ' $<0.05$.

\begin{tabular}{|c|c|c|c|c|c|c|c|}
\hline & Estimate & Std. & Sum of sq & Df & F value & Proba (>F) & \\
\hline (Intercept) & 66.79 & 65.09 & & & & & \\
\hline TEP & 61.76 & 22.30 & 32482 & 1 & 27.94 & $<0.0001$ & $* * *$ \\
\hline NO3 & -2.99 & 1.13 & 30351 & 1 & 26.11 & $<0.0001$ & $* * *$ \\
\hline bacteria & -176.4 & 74.1 & 16159 & 1 & 13.90 & 0.0017 & $* *$ \\
\hline interaction tep x bacteria & 69.1 & 31.5 & 5605 & 1 & 4.82 & 0.042 & $*$ \\
\hline interaction NO3 x bacteria & -4.18 & 1.67 & 7262 & 1 & 6.25 & 0.023 & $*$ \\
\hline Residuals & & & 19761 & 18 & & & \\
\hline
\end{tabular}


811 